\title{
Antagonising Chromatin Remodelling Activities in the Regulation of Mammalian Ribosomal Transcription
}

\author{
Kanwal Tariq (D) and Ann-Kristin Östlund Farrants *(D) \\ Department of Molecular Biosciences, The Wenner-Gren Institute, The Arrhenius Labs F4, Svante Arrhenius väg \\ 20C, Stockholm University, SE-106 91 Stockholm, Sweden; kanwal.tariq@su.se \\ * Correspondence: anki.ostlund@su.se; Tel.: +46-8164-097
}

Citation: Tariq, K.; Östlund Farrants, A.-K. Antagonising Chromatin Remodelling Activities in the Regulation of Mammalian Ribosomal Transcription. Genes 2021, 12, 961. https://doi.org/10.3390/genes12070961

Academic Editor: Konstantin Panov

Received: 24 May 2021

Accepted: 19 June 2021

Published: 24 June 2021

Publisher's Note: MDPI stays neutral with regard to jurisdictional claims in published maps and institutional affiliations.

Copyright: (c) 2021 by the authors. Licensee MDPI, Basel, Switzerland. This article is an open access article distributed under the terms and conditions of the Creative Commons Attribution (CC BY) license (https:// creativecommons.org/licenses/by/ $4.0 /)$.

\begin{abstract}
Ribosomal transcription constitutes the major energy consuming process in cells and is regulated in response to proliferation, differentiation and metabolic conditions by several signalling pathways. These act on the transcription machinery but also on chromatin factors and ncRNA. The many ribosomal gene repeats are organised in a number of different chromatin states; active, poised, pseudosilent and repressed gene repeats. Some of these chromatin states are unique to the 47rRNA gene repeat and do not occur at other locations in the genome, such as the active state organised with the HMG protein UBF whereas other chromatin state are nucleosomal, harbouring both active and inactive histone marks. The number of repeats in a certain state varies on developmental stage and cell type; embryonic cells have more rRNA gene repeats organised in an open chromatin state, which is replaced by heterochromatin during differentiation, establishing different states depending on cell type. The 47S rRNA gene transcription is regulated in different ways depending on stimulus and chromatin state of individual gene repeats. This review will discuss the present knowledge about factors involved, such as chromatin remodelling factors NuRD, NoRC, CSB, B-WICH, histone modifying enzymes and histone chaperones, in altering gene expression and switching chromatin states in proliferation, differentiation, metabolic changes and stress responses.
\end{abstract}

Keywords: rRNA gene repeats; chromatin states; NuRD; B-WICH; NoRC; histone modifications; non-coding RNA

\section{Introduction}

Ribosomal genes, both the nucleolar 47S genes and the 5S rRNA genes, are highly transcribed and contribute to the major part of all transcripts. The expression is tightly coupled to proliferation and cell growth with a high demand for protein synthesis [1-3] in mammalian cells. Therefore, ribosomal gene transcription is often dysregulated in highly proliferating cancer cells and is a target for novel cancer drugs [2-6]. Ribosomal transcription is regulated by environmental cues, such as changes in nutrient and energy supply, and thereby adjusts transcription and energy consumption $[1,7,8]$. The two ribosomal genes are transcribed by their own transcription machineries: 47S rRNA genes by RNA polymerase I (RNA pol I) and 5S rRNAs by RNA pol III. In addition, ribosomal transcription encompasses the transcription of ribosomal protein-coding genes by RNA pol II which is coordinated with the transcription by RNA pol I and RNA pol III [9]. Although the ribosomal genes are regarded as house-keeping genes recent studies have identified cell-type-specific expression, giving rise to tissue specific ribosomes with varying activity and specify $[10,11]$. Variations in ribosomal biogenesis, in particular in rRNA modifications, also contribute to the heterogeneity of ribosomes $[12,13]$.

Ribosomal biogenesis takes place in the nucleolus, a membrane-less nuclear body that forms around active Nuclear Organising Regions (NORs), after each mitosis [14]. The NORs comprise gene clusters of the rRNA gene organised head to tail separated by an intergenic spacer region (IGS) $[1,7,15]$. Transcription of the genes, the processing and 
cleavage of the 47S rRNA transcript and the subsequent assembly of ribosomal RNAs and protein subunits occur in specific internal nucleolar structures dedicated to the different processes. The fibrillar centre (FC) assembles around active rRNA gene repeats associated with the RNA pol I factor upstream binding factor (UBF), the gene transcription occurs in the interface between the FC and the dense fibrillary centre (DFC), where processing and cleavage of the 47S rRNA take place, followed by the assembly of the rRNAs with ribosomal proteins to ribosomal subunits in the granular centre (GC) [16-19]. The formation of the nucleolar structures depends on transcriptional activity and when inhibited or very low, nucleolar structures are disrupted and nucleolar proteins are delocalised; fibrillarin, which is responsible for the 2'-O-methylation of rRNA early in the FC [6,20], and UBF translocate to the periphery, forming nucleolar caps (Figure 1A). Other abundant nucleolar proteins, such as the multifunctional proteins nucleolin, involved in activating rRNA gene transcription [21,22], and nucleophosmin (NPM), mainly involved in ribosomal assembly and export [22,23], are also leaving the nucleolus upon transcriptional inhibition and stress. The formation of the different nucleolar centres and the integrity of the nucleolus are based on phase separation and each centre contains many RNAs and several RNA binding proteins with intrinsically disordered domains [24]. Fibrillarin associates cotranscriptionally with the $5^{\prime}$-end of the growing rRNA chain in the FC and forms phase separated condensates representing DFCs [25]. Nucleolin and NPM are also involved in phase separation; nucleolin retains histone $\mathrm{H} 2 \mathrm{~B}$ in the nucleolus in a pre-rRNA dependent manner [26] and NPM is involved in protein quality control by forming phase separation condensates with misfolded proteins in the GC [27].

A

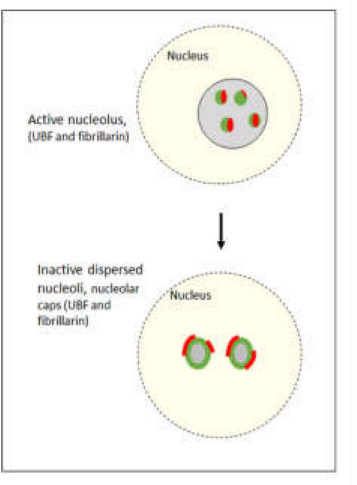

B

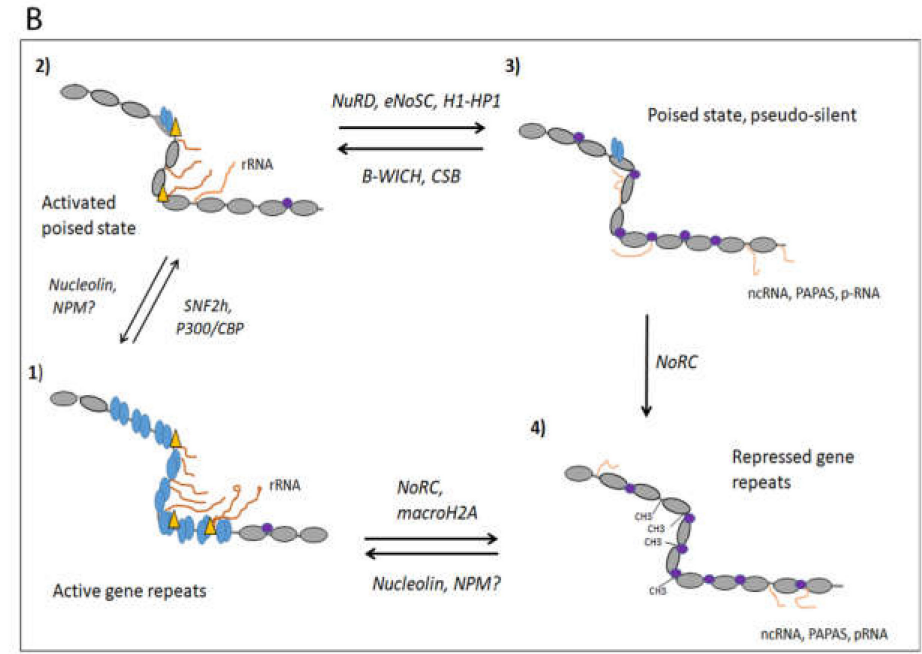

Figure 1. (A) The nucleolar integrity in active and dispersed nucleoli. Nucleolus with several FCs reflecting active transcription, with UBF (green) and fibrillarin (red) assemblies surrounded by GC. (top panel), and nucleus exposed to stress such as DNA damage or starvation, reducing transcription, leading dispersed nuclei with a different organisation, here shown with nucleolar caps, UBF (green) and fibrillarin (red) at the periphery and GC-component in the interior (bottom panel). (B) Different chromatin states of the mammalian rDNA and the chromatin remodelling complex identified. (1) The active chromatin state is organised with UBF (bleu ovals), which imposes an open, decondensed chromatin state that is transcriptionally active if induced by transcription factors (RNA pol I is marked with a yellow triangle), with nucleosomal chromatin (grey ovals) in the IGS; (2) the activated poised state, organised with nucleosomes (grey ovals) and is transcriptionally active (RNA pol I is depicted with a yellow triangle, (3) the permissive poised state or the pseudosilent state, organised with nucleosomes carrying histone PMTs and heterochromatin factors (marked with purple circles), and transcriptionally inactive, (4) the constitutively repressed chromatin state, organised in heterochromatin with DNAmethylations and is transcriptionally silent. The chromatin remodelling complexes and histone chaperones involved in the switches between states are depicted around the arrows. RNAs are shown, the sense 47S rRNA transcript in (1) and (2) and ncRNA species from the IGS in (3) and (4). 
The nucleolus is also the target of several stress responses, such as heat shock, hypoxia, and DNA damage, all of which affect the expression of the 47S rRNA transcription $[1,7,8]$. In addition, nucleolar structure and function are disturbed in many viral infections to channel the resources to promote viral replication [27]. Many viruses accumulate in the nucleolus and bind to nucleolar proteins such as nucleolin, NPM and fibrillarin, to interfere with their function and 47S rRNA gene expression [28]. The many functions that congregate in the nucleolus and impact the $47 \mathrm{~S}$ rRNA gene expression link nucleolar function closely to the status of the cell. The nucleolus constitutes a hub for responses, hence the 47S rRNA transcription is regulated by environmental states and stress on several levels; modification of the RNA pol I machinery and the chromatin landscape as well as altering nucleolar morphology and structure to alter the expression level. This review will focus on the regulation of $47 \mathrm{~S}$ rRNA gene repeats in mammalian cells.

\subsection{The Active $47 S$ rRNA Gene Transcription Is Organised in an Open Chromatin State}

The human haploid genome harbours approximately 200 gene repeats found in clusters located on five acrocentric chromosomes, chromosome 13, 14, 15, 21 and 22 [7,8]. Not all genes are active in differentiated cells and some gene repeats are gradually silenced by the establishment of heterochromatin during differentiation $[7,29-31]$. The number of active gene repeats correlates to the requirement for protein synthesis in each cell but since the 47S rRNA transcription also needs to be adjusted according to cellular state and environmental conditions, several regulatory mechanisms exist also in differentiated cells. During differentiation, the gene repeats acquire different chromatin states with different compactions to meet changes in the cell. At least four different states, from open active gene repeats and to closed repressed gene repeats, have been identified (Figure 1B) [32-37].

The active $47 \mathrm{~S}$ rRNA gene repeats are organised with the high motility group (HMG) protein UBF, which binds at the at the enhancer element, UCE, in the promoter, but also in the gene body and the upstream enhancer region $[31,33,35,37]$. UBF binds to UCE as a dimer covering approximately $140 \mathrm{bp}$ of DNA in a single turn $[35,38]$, and interacts with the TBP-containing TAFI-SL1 complex which binds at the core promoter at the transcription start site $[39,40]$. The UBF and SL1 recruit the RNA pol I bound to the axillary factor TIF-1A/RRN3 to form the pre-initiation complex (PIC) (Figure 2) [39-41]. UBF establishes an open chromatin state specific to the active $47 \mathrm{~S}$ gene repeats [42] and is associated with GC-rich DNA at approximately every $170 \mathrm{bp}$ in the gene body [37]. A further promoter [43], the spacer promoter binding UBF and SL1, is located approximately two kb upstream of the transcription start $[35,37]$. RNA pol I and TIF-1A/RRN3 are also found at the spacer promoter and a non-coding RNA (ncRNA), the spacer RNA, is produced in mouse [44-46]. Upstream of the spacer promoter is the boundary element, binding CTCF and cohesin, separating the nucleosomal IGS from the active UBF associated gene repeat $[35,37,47-49]$. The enhancer boundary element is in turn flanked by three to four positioned nucleosomes containing $\mathrm{H} 3 \mathrm{~K} 4 \mathrm{me} 2 / 3$ and $\mathrm{H} 2 \mathrm{~A}-\mathrm{Z}$, indicating that the boundary constitutes an insulator (Figure 2). Similar enrichment of RNA pol I factors has been found in human cells approximately $800 \mathrm{bp}$ upstream of transcription start site, with an enrichment of CTCF [37,48]. In the human IGS, a third promoter two kb upstream of the transcription start site in human cells was identified, from which an antisense RNA of unknown function is produced [50]. The open structure organised with UBF is particularly abundant in ES cells (embryonic stem cells) and mouse embryonic fibroblasts (MEFs), where few histone marks are found in the 47S rRNA gene repeat $(35,37)$, whereas that of differentiated cells may contain more histones (49). Interestingly, malignant human hepatocytes, HepG2, exhibit an increase of histone H3K4me3 approximately at the spacer promoter compared to control cells, and this is reduced when UBF is silenced. 


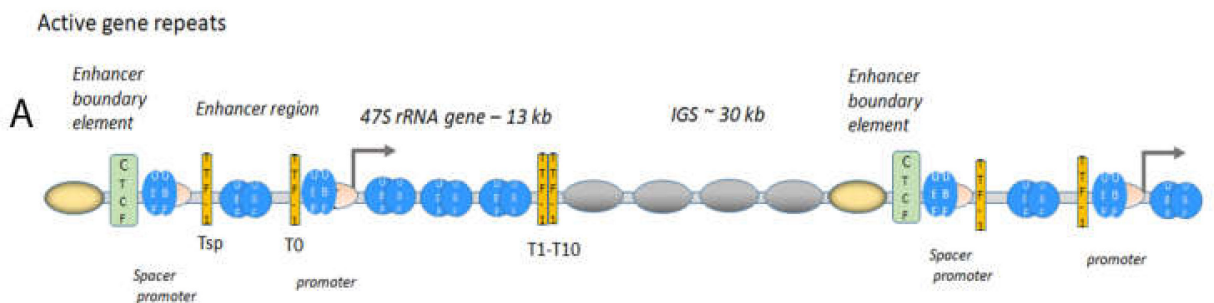

Nucleosomal gene repeats

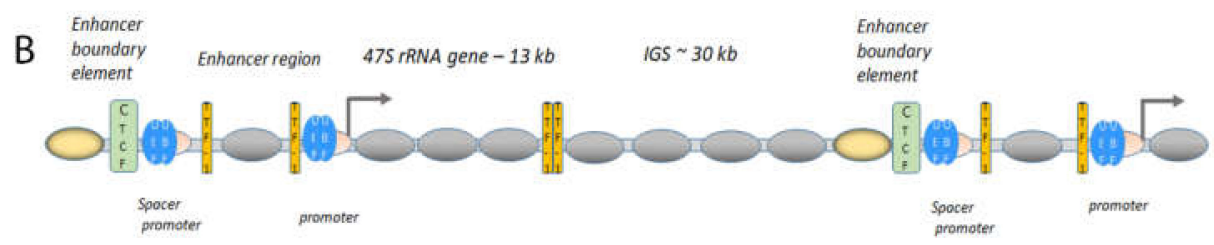

Figure 2. Chromatin architecture at the rDNA at the active (A) and the poised state (B). (A) The genes are organised head-to-tail; UBF (bleu ovals) and SL1 (pink crescent) are bound to the promoter and the spacer promoter (depicted in the figure). TTF-1 (yellow bars) is bound to its binding sites, depicted Tsp downstream of the spacer promoter, T0 at the promoter, and T1-T10, at the end of the $47 \mathrm{~S}$ rRNA gene. UBF is associated with the active 47S rRNA gene body and with the upstream enhancer region and the IGS downstream of the termination of the gene (T1-T10) is nucleosomal (grey ovals). CTCF (green rectangle) is flanking the spacer promoter with positioned nucleosomes with active histone marks and H2AZ (yellow oval nucleosome). These actively marked nucleosome are also present in the poised state in the bottom panel). (B) The poised state have nucleosomes (grey ovals) in the gene repeat, UBF (bleu ovals and SL1 (pink crescent) at the promoter and spacer promoter. TTF-1 (yellow bars) is binding to its sites, Tsp, T0, T1-T10 in the gene repeat. CTCF (green rectangle) is also here flanking the spacer promoter with positioned nucleosomes with active histone marks and H2AZ (yellow oval nucleosome).

\subsection{The Boundary Element, a Form of Insulator, Is Important in the Maintenance of Chromatin} States and Factor Loading

The boundary element functions as an insulator between chromatin configurations and may also represent a nucleation site for assemble factor that are responsible for switching chromatin structures (Figure 2). Several line of evidence support such an organisation: interfering with the composition of the element by siRNA silencing of CTCF impairs the loading of UBF on the 47S gene repeats [47] allowing for nucleosomes entering the gene repeats $[32,34-36,42,49]$. The boundary element and the adjacent active histones are present also in repressed gene repeats, suggesting that this site is a "marked" site and involved in establishing the active chromatin state $[31,35,37]$. Furthermore, the boundary element is enriched in chromatin remodelling ATPase SNF2h and the histone acetyl-transferase (HAT) p300, both of which are involved in altering chromatin configurations. The organisation of gene repeats with UBF is not sufficient for transcription, some of the active repeats are not engaged in transcription [35,37], and other factors, such as transcription factors, may be necessary for proper PIC formation to induce transcription.

\subsection{Gene Expression of Active Gene Repeats Requires Transcription Factors}

Initiation and elongation of the $47 \mathrm{~S}$ rRNA transcription are rate limiting steps in responses to environmental cues without changing the chromatin state [42,51-53]. Enhancing elongation is the mauclein regulatory step in response to acute growth factor stimulation when the PIC is still in place, possibly by phosphorylation of UBF in the gene body $[52,54]$. Growth factor stimulation for cells in G1/G0, for instance after long-term, chronic starvation, requires PIC formation, RNA pol I loading as well as elongation regulation [52]. None of these regulatory steps require a change in chromatin states. This is further sup- 
ported by the activation of 47S rRNA gene transcription of the proliferative transcription factor c-MYC in pre-malignant murine B-cells that occurs without a change in open UBF gene repeats organised with UBF [53]. Taken together, this suggest that the decondenced chromatin state organised with UBF forms the basis for transcription, as the competent state $[53,55]$ (Figure 1B, panel 1), which is activated by specific transcription factors and by post-translational modification (PMT) of general factors.

\subsection{Active Gene Repeats Form Loops}

Directly upstream of the UCE in the promoter, a binding site, T0, for transcription termination factor 1 (TTF-1) is located [56], and a similar site, Tsp, is also found at the spacer promoter, located 40 to $50 \mathrm{bp}$ downstream of the UCE in mouse and human cells (Figure 2) [25,37]. Several TTF-1 sites, the Sal-boxes or T1-T10, are located at the end of the rRNA gene repeat to terminate the $47 \mathrm{~S}$ rRNA transcription and it is also a replication fork barrier $[57,58]$. The function of the gene upstream sites is possibly to terminate ncRNAs produced upstream of the promoter, but the spatial organisation promotes interactions to form loops [59-61]. The spatial organisation of the active gene repeats in the nucleolus studied by super-resolution imaging techniques shows that RNA pol I forms ring structures with a size suggesting that active genes are organised in loops of one or a few genes being loaded with UBF or nucleosomes [25,62]. These loops may represent the loops between TTF-1 identified with 3C-techniques [59] or loops with CTCF [60,63]. It is not clear if the loops are formed between the promoter and the terminator of the same gene or proximal gene repeats or in what chromatin state these gene repeats are present, but the looping makes transcription more efficient.

\subsection{Acetylation of UBF Enhances $47 S$ rRNA Gene Transcription}

Similar to histones, UBF is acetylated by histone acetyl-transferases (HATs), particular p300/CBP, and deacetylated by histone deacetylases (HDACs) to regulate the 47S rRNA expression $[64,65]$. Ribosomal transcription is altered through the cell cycle and UBF-Ac is higher in G2 when the transcription also is highest [66]. CBP acetylates UBF in S-phase to increase the interaction with PAF53, a RNA pol I associated factor, resulting in an increased 47S rRNA expression. Lack of acetylation of UBF also contributes to the reduced 47S rRNA transcription observed in a human Huntington disease model, suggested to be caused by the mutated Huntingtin protein sequestering the CBP protein [67]. Other HATs have been identified among processing factors and hALP and 16A/DRIM, t-UTP U3 processing factors, acetylate UBF which increases its interaction with RNA pol I [68,69].

\section{The Inactive 47S rRNA Gene Repeats Are DNA Methylated and Organised in Constitutive Heterochromatin}

The 47S rRNA gene repeats are maintained in and open chromatin state early in development, and then subsequent silencing of gene repeats is an important process during differentiation [70]. In the early embryo, most rRNA gene repeats are loaded with $\mathrm{UBF}$ and actively transcribed to meet the requirement of protein synthesis in the rapidly dividing cells $[34,36,70,71]$ (Figure 1B, panel 1). The chromatin remodelling complex NoRC, composed of TIP5 (TIF interacting protein 5), the ATPase SNF2h, HDAC1, the histone methyl-transferase (HMT) SUV39H1, the DNA methylase DNMT3b is instrumental in establishing heterochromatin at the rDNA to reduce the 47S rRNA gene transcription [72]. It is also involved in establishing heterochromatin outside of the nucleolus, on centric and peri-centric repeats as well as major and minor repeats and at LINE elements [73]. The NoRC complex contributes to the restructuring of the nuclear architecture during embryogenesis by silencing active chromatin regions at repetitive regions.

The repressed state established by NoRC is characterised by repressive chromatin marks, heterochromatin factors, and methylated DNA [72,74-76] (Figure 1B, panel 4). The complex is recruited to the promoter by TIP5 binding to TTF-1 [56,77], histone H4Ac [76,78,79] and linker DNA [80]. At the promoter, NoRC moves a promoter-bound nucleosome to a "closed" position incompatible with the assembly of the pre-initiation 
complex $[76,80,81]$. The closed promoter-bound nucleosome position ( -132 to $+22 \mathrm{bp})$ covers the core promoter and transcription start site, preventing SL1 from binding and initiating transcription. Subsequently the p-RNA, a fragment from the spacer-RNA, forms a triple helix with the T0 site, replaces TTF- 1 and binds to TIP5 [45,46,75]. The p-RNA inhibits the ATPase activity of NoRC, which instead recruits the silencing factors HDACs, SUV39H1, and DNMT3 [81]. The conversion to heterochromatin involves the deacetylation of histones at the promoter, and the introduction of histone methylation, $\mathrm{H} 3 \mathrm{~K} 9 \mathrm{me} 2 / 3$, and DNA methylation, which together reduces the binding of UBF [74]. The DNA-methylated promoter-bound nucleosome in quiescent cells also carries the histone modification histone H4K20me3 [82]. This histone modification is established by SUV420, and the protein is recruited to the rRNA promoter by the anti-sense transcript PAPAS (promoter and pre-rRNA antisense) [82]. This transcript is produced by RNA pol II in the antisense direction to the 47S rRNA, originates from the gene body but also includes reads through to the promoter, and is increased upon reduced levels of sense-transcription [82].

Histone variants of the canonical histones have been associated with rDNA. The DNA-methylated state binds macroH2A, which is associated with silent chromatin [83]. It accumulates on the rRNA gene promoter and maintains a silent chromatin state. Histone $\mathrm{H} 1$ is also associated with the silent gene repeats. Different $\mathrm{H} 1$ variants interact with silencing factors in the nucleolus, such as macroH2A, heterochromatin proteins $1 \alpha(\mathrm{HP} 1 \alpha)$, $\mathrm{HP} 1 \beta$, and HP1 $\gamma$ and DNMT3a/b, but also with active factors, such as UBF, nucleolin and topoisomerase I [84-86]. Histone H1.2 interacts with UBF in mitotic NORs [87]. The binding of $\mathrm{H} 1$ variants also affect the rRNA gene transcription, where deletion of UBF [32] and Actinomycin D [88] increase H1 and HP1 association with the rRNA gene repeat. However, phosphorylated H1.4 co-localises with fibrillarin and actively transcribed rRNA [88]). Whether histone H1 and HP1 is functioning with NoRC is not clear but it does not exclusively associate with DNA methylated promoters, which suggests that it also is present in other chromatin states.

\section{The Switch between Active and DNA-Methylated Inactive 47S rRNA Gene Repeats}

The switch between active and DNA methylated inactive states involves the NoRC complex, which replaces UBF for nucleosomes in a process that occurs mainly during differentiation, embryonic development and malignant transformation. The switch employs specific transcription factors, chromatin remodelling and histone PTMs (Figure 1B, panel 1 and 4). The transcription factors recruit HDACs and SIRTs (NAD-dependent histone deacetylases) as well as histone HMTs, such as SUV39H1, either directly or as part of the NoRC complex to silence the genes [7,72]. The general transcription repressor BEND3 associates with the 47S rRNA and in its SUMOlated form interacts with NoRC and stabilises TIP5 by inhibiting its degradation through ubiquitination [89]. Furthermore, a number of bridging factors have been identified that respond to signalling pathways and affect the chromatin state. The activation of the 47S rRNA gene transcription by mTOR in human cell is counteracted by the tumour suppressor inhibitor of growth (ING1) [90]. ING1 is recruited to active rDNA by histone H3K4me3, and it recruits in turn the NoRC complex, which results in the establishment of heterochromatin and reduced 47S rRNA gene transcription. ING1 also inhibits the localisation of mTOR to the nucleolus. RUNX2, important in osteoblast differentiation, is not silencing rRNA gene repeats by NoRC, instead it binds the 47S rRNA gene promoters, recruit HDAC1 to deacetylase UBF, which leads to a decrease in RNA pol I transcription [91].

During development of certain lineages, transcription must be reactivated to allow for cellular transitions. This occurs in the epithelial-to-mesenchymal transition (EMT) in cells that need to develop a migratory cellular program, such as neural crest progenitor cells in early development. A temporary increased ribosomal transcription in G1/S-phase is required for EMT and is executed by the EMT-specific transcription factor Snail and the mTORC2 component Rictor [92]. The increase in transcription is associated with reduced DNA-methylation and replacement of TIP5 by UBF. A similar process is also found in 
cancer cells that rely on EMT for metastasis. It is not known if a chromatin-remodelling factor is involved in the antagonistic effect to NoRC in this process.

Little is known about the switch between rRNA repeats silenced with the histones variants macroH2A and $\mathrm{H} 1$ and active genes. If these gene repeats also exhibit further attributes of NoRC silenced chromatin than DNA-methylation is not known. Nevertheless, nucleolin counteracts the silent state imposed by macroH2A by increasing UBF loading along the rRNA gene body and increasing the presence of active histone marks at the promoter [83,93]. Nucleolin may act as a FACT-like H2A-H2B histone chaperon [94,95], removing macroH2A which leads to UBF loading, preventing TTF- 1 binding to the T0 and the subsequent recruitment of TIP5 and NoRC [93]. In addition, inhibition of rRNA gene transcription results in higher levels of macroH2A at the $47 \mathrm{~S}$ rRNA gene repeat, suggesting that both changes in nucleolin levels in the nucleolus and transcription leads to switches in chromatin state. Depletion of nucleolin affects the RNA pol I levels at the $5^{\prime}$ end of the rRNA gene body, suggesting that not only transcriptional initiation but also elongation is affected. A similar effect is shown by the H2A-H2B histone chaperone FACT, which facilitate elongation through the gene body $[96,97]$. NPM/B23 also function as a histone chaperone at the promoter, requiring its RNA-binding domain and UBF to be recruited to the gene [98]. NPM inhibits histones and possible histone H1 [99] to associate with the 47S rRNA gene repeat and maintain and open chromatin structure [98]. Altering the binding of core histones and linker histones to the promoter or the gene body is one way to change the chromatin states of rRNA gene repeats and regulate gene expression. Nucleolar histone $\mathrm{H} 1$ interacts with both activating and repressing factors and is suggested to be involved in regulating different states. Several of the $\mathrm{H} 1$ isoforms have been localised to the nucleolus; H1.0, H1.2, H1.3 [86] and phosphorylated forms of H1.2 and H1.4 [88]. Phosphorylated histone $\mathrm{H} 1.2$ and in particular histone H1.4 associate with active 47S rRNA genes repeats and rRNA inhibition reduces the phosphorylation level. Histone H1 interacts with the histone chaperones nucleolin, NPM, subunits of FACT as well as the heterochromatic proteins macroH2A, and $\mathrm{HP} 1$ and the active proteins $\mathrm{UBF}$, histone $\mathrm{H} 2 \mathrm{AZ}$, histone $\mathrm{H} 3.3$ and DNA topoisomerase II $[84,86,87]$. The interaction of histone $\mathrm{H} 1$ with several histone chaperones indicates that one function of the chaperones is to regulate histone $\mathrm{H} 1$ and UBF and their PMT at the promoter. Interestingly, H1 knock out gives more DNMT3a/b as well as proteins involved in chromatin remodelling, such as WSTF and BRG1, enriched in the nucleolus, indicating that chromatin changes and DNA methylation are involved in the regulation $[85,100]$. The changes caused by the histone variants and nucleolar chaperone proteins do not change the DNA-methylation fraction of gene repeats $[49,83]$ which suggests that more chromatin states exist, constituted of nucleosomal chromatin on non-DNA-methylated 47S rRNA repeats.

\subsection{The Permissive Poise Chromatin State Is Organised in Bivalent Chromatin on Unmethylated DNA}

The rRNA gene promoters adopt further chromatin states than the active and repressed gene states referred to as the poised and pseudo-silent states, which in contrast to the repressed promoters silenced by NoRC, assemble on unmethylated DNA. The exact compositions of these states are largely unknown and they may constitute a group of differently organised nucleosomal gene repeats $[31,37,49,101]$ with cell type specificity. The promoters carry UBF and SL1 as well as nucleosomes with bivalent chromatin marks [101] or histone H1 and HP1 [32,34]. The ChIP seq studies [33,35,37,49] of mouse and human rDNA suggest that the poised or pseudo-silent state is essentially nucleosomal and the active gene repeats with an open chromatin configuration are organised with UBF. In mouse, the poised state is associated with the two ATP-dependent chromatin remodelling complexes Cockayens syndrome protein B (CSB) and CHD4/ nucleosome remodelling deacetylase (NuRD), which act on the promoter nucleosomes (Figure 1B, panel 2 and 3) [101]. CSB and CHD4, the ATPase in the NuRD complex, are recruited to the promoter by TTF-1 during growth arrest and differentiation [101,102]. NuRD is responsible for the positioning of the promoter-bound nucleosome in the closed state covering the core 
promoter and transcription start site [101]. Although the position of the "closed" poised nucleosome is the same as that of the "closed" nucleosome formed by NoRC [81], the associating factors are different; the poised nucleosome carries both activate and silence histone marks, the active H3K4me3 and the two silencing H3K27me3 and H3K9me2/3, but no H4K20me3. It also differs from the NoRC "closed" nucleosome in that it is devoid of methylated DNA and associates with both UBF and SL1. Despite that UBF and SL1 are present at the promoter, TIF-1/RRN3 and RNA pol I are excluded [101], which shows that the poised closed nucleosome is not compatible with the assembly of the PIC. NuRD is suggested to prevent DNA methylation of the promoter, but still keep a poised pool of $47 \mathrm{~S}$ rRNA gene repeats available for activation [101].In support of this, NuRD also inhibits TIP5 expression, indirectly contributing to inhibit the DNA methylation of rRNA repeats [103].

\subsection{The Activation of the Permissive Poised State Involves Establishing an Active Nucleosome State}

The poised "closed" marked nucleosome at the promoter is moved by the ATPase CSB to an active position ( -157 to -2$)$, compatible with TIF-1A/RRN3 and RNA pol I binding (Figure 1B, panel 2 and 3) [101]. CSB then recruits PCAF to the promoter to acetylate histone $\mathrm{H} 4$ and histone $\mathrm{H} 3 \mathrm{~K} 9$, creating an active configuration with histone $\mathrm{H} 4 \mathrm{Ac}$ and histone H3K9Ac [104]. CSB associates also with the gene body, where it recruits the histone methyl transferase G9a to activate transcription by increasing the level of histone H3K9me2 and HP1 $\gamma$ in the region [102]. Recently, CSB together with CSA was shown to regulate transcription elongation mainly by recruiting nucleolin in human cells [105].

In addition to CSB, the poised state induced by the NuRD complex is counteracted by the ATP-dependent chromatin remodelling complex B-WICH (Figure 1B, panel 2 and 3). BWICH, comprising WSTF, the ATPase SNF2h and nuclear myosin $[106,107]$, activates rRNA gene transcription by establishing a more open chromatin configuration at the promoter to allow SL1, TIF-1A/RRN3 and RNA pol I to bind $[108,109]$. This state is characterised by the binding of UBF and a high histone H3K9Ac level at the promoter in human cells [108]. An impaired B-WICH complex, obtained by RNAi silencing of WSTF, results in CHD4 not being released from the promoter after glucose stimulation, suggesting that $\mathrm{B}-\mathrm{WICH}$ is required to replace $\mathrm{NuRD}$ to open up the chromatin to allow the pre-initiation complex to form [109]. B-WICH also allows other factors, such as c-MYC, to bind to the promoter and enhance expression of the genes [109].

\subsection{Transcriptions Factors, c-MYC, Induce Chromatin Changes and Activate Gene Expression}

c-MYC is a transcription factor that regulate ribosomal and metabolic genes in response to proliferative stimulus and in complex with MAX binds to several position in rDNA, including a site in the $47 \mathrm{~S}$ gene promoter $[110,111]$. NPM facilitates the nucleolar entry of c-MYC and its transcription activation [112]. c-MYC recruits the TRRAP co-regulatory complex that contain the HATs GCN5, TIP60 and PCAF, which acetylate histones in the promoters [113]. c-MYC is also involved in the induction 47S rRNA gene transcription in hypertrophic mouse muscle, where it associates with the promoter together with WSTF [114]. B-WICH opens up chromatin for c-MYC-MAX binding in the intergenic spacer between the $5 S$ rRNA genes, which is a pre-requisite for histone modifications and transcription [115]. Along with regulating the ribosomal gene transcription directly, c-MYC regulates the expression of RNA pol I factors [116]. The regulation of c-MYC influences ribosomal transcription and some pathways are targeting both c-MYC and ribosomal factors; c-MYC and UBF are degraded following SUMOlation by PIAS E3 ligases [117] and c-MYC mRNA stability is coordinated with 47S rRNA gene transcription through the RNA guanine-7 methyltransferase in the mRNA cap [118].

c-MYC is dysregulated in cancer [119] usually with a concomitant increase in $47 \mathrm{~S}$ rRNA gene transcription. This increase may be linked to a change in chromatin state at $47 \mathrm{~S}$ rRNA gene repeats but may also result in other changes. In contrast to c-Myc expression in murine pre-malignant B-cells which have an enhanced rRNA transcription without chromatin changes, the malignant transformed cells have an increased number of active 
gene repeats, but no change in gene expression occurred [53]. Instead, a higher extent of interactions between UBF organised rRNA gene repeats and RNA pol II genes in the peri-nucleolar region appeared [53]. These UBF organised gene repeats were shown to display an enhanced interaction with RNA pol II gene enhancers in the peri-nucleolar region. The UBF has been shown to associate with a subset of highly expressed RNA pol II genes [120]. The change in chromatin state in malignant transformed cells, referred to as the rDNA class switching, does not involve changes in DNA methylation, most likely switching an unmethylated repressed pool of 47S rRNA gene repeats [53], such as the poised or pseudo-silent state.

In addition to c-MYC, other factors, such as ING4, are involved in activating transcription by altering the chromatin configuration. ING4 activates transcription by inducing histone H3K9Ac and histone H4Ac and increasing the level of UBF at promoters [121]. It is not known whether these transcription factors activate 47S rRNA gene transcription by altering both active gene repeats and permissive poised repeats at the same time and by the same mechanism, recruiting chromatin remodellers or histone modifying complexes.

\subsection{HATs and HDACs Are Involved in Chromatin Changes}

HATs, such as MOF, p300/CBP, PCAF, GCN5, TIP60, are associated with the switch to an active state introducing histone H3Ac and histone H4Ac [49,72,78,101,108], functioning with transcription factors, such a c-MYC. In tumour cells, overexpression of LYAR, a transcription factor in inflammatory pathways, also MYST/KAT7 bound to BRD2 and BRD4 associates to UBF to acetylate histone $\mathrm{H} 4$ and $\mathrm{H} 3$ [122]. Not only acetylation of histones and UBF is associated with activation; subunits in SL1 acetylated by PCAF [123], which are deacetylated by the NAD-dependent SIRT1 to inhibit transcription during mitosis [124]. SIRT7 is a further NAD-dependent deacetylase associated with ribosomal transcription, but unlike SIRT1, it is an activator [125]. SIRT7 localises to the nucleolus, it interacts with UBF and is required for the release from mitosis [126,127]. SIRT7 has many targets in the nucleolus affecting both transcription and processing that have been acetylated by CBS; PAF53, an RNA pol I associated factor, to activate transcription [128], the helicase DDX21 to resolve R-loop [129] and U3-155, NOP56 and fibrillarin, to promote processing and cleavage of the $47 \mathrm{~S}$ rRNA [130,131]. SIRT7 also deacetylate fibrillarin at the exit of mitosis promoting methylation of histone H2A at glutamine 104 (H2AQ104), which decompacts the promoter to resume transcription $[129,132,133]$. Other active histone marks in RNA pol II transcription, such as H3K4me3 and H3K36me3, are also present 47S rRNA gene repeats, most likely at the permissive poised state [101]. These modifications are altered by the histone demethylases KDM2A/B, in response to glucose starvation and metabolites through AMPK pathway and HP1 $\gamma$ recruitments [134-138]. Two histone demethylases, PHD8 and KDM4B, are involved in switching to an active chromatin state by removing methyl groups from histone H3K9me3/2n [139], PHD8 in response to PIP2binding [140]. The fact that many histone modifying enzymes associate with the promoter suggests that they modify nucleosomes in the permissive poised or pseudo-silent state and facilitate the switch to an active nucleosomal state.

\section{5. eNOSC Induces Silencing in Response to Low NADH-Levels}

A low energy level is sensed as an increased AMP/ATP ratio by the AMPK pathway, which downregulates several processes to save energy, among those the 47S rRNA gene transcription [141]. The AMPK inhibits mTOR which reduces the rRNA gene transcription by inhibitory phosphorylation of TIF-1A/RRN3 and UBF [142-145] to prevent the preinitiation complex from forming [146]. In HeLa cells, which lack the AMPK-pathway, a chromatin-remodelling complex, eNoSC, which senses a reduced energy level in the form of an increased NAD+ level has been identified [147]. The eNoSC, comprising nucleomethylin (NML), SIRT1 and SUV39H1, is recruited to the promoter by nucleosomes harbouring $\mathrm{H} 3 \mathrm{~K} 9 \mathrm{me} 2$ and in turn establishes heterochromatin by deacetylation and methylation of histone H3K9 [147]. NML also binds to the 47S rRNA and associates with the 
promoter first when released after reduction in transcription $[148,149]$. The NML protein is also involved in rRNA methylation and function through p53 in senescence [150,151]. Since eNoSC only associates with the promoter after transcription is reduced it is most likely that the complex functions in the maintenance of a silent chromatin in the energy saving pathway rather than in establishing a silent chromatin state. In addition to eNOSC, NuRD establishes a repressed chromatin state in glucose starved cells, and we propose that B-WICH counteracts this chromatin structure upon glucose stimulation [109].

\section{Acute Stress Responses and the Regulation of rRNA Transcription}

The nucleolus acts as a hub for different stress responses, such as viral infections, hypoxia and heat shock, and these responses reduce the 47S rRNA gene transcription. Many stress responses are sensed by signals and targets the RNA pol I factors directly, which inhibit the assembly of the PIC but others are altering the chromatin states at the genes. Hypotonic stress [152] and heat shock [153,154] require the NuRD complex to establish a silent state at the promoter. SUV420, which is recruited by PAPAS during growth arrest to establish a compaction of the chromatin, is degraded by the E3-ligase NEDD4 during stress [152]. This leaves the PAPAS, which forms a triple helix with the enhancer element at the promoter, to bind to and recruit the dephosphorylated CHD4 in the NuRD complex to the promoter [154]. The mouse cells, the PAPAS is induced by heat shock and hypotonic stress by the simultaneous dephosphorylation of TIF-1A/RRN3 as CHD4 $[153,155]$, and this results in reduced rRNA gene transcription and an increased PAPAS production.

\subsection{IncRNA Originating from the Human IGS Are INVOLVED in Stress Responses with Reduced 475 rRNA Gene Transcription}

pRNA and PAPAS are not found in human cells, but a number of ncRNAs that originate from the IGS have been identified. These are associated with different stress responses; heat shock induces the expression of transcripts, IGS16, and IGS22, originating from loci 16 $\mathrm{kb}$ and $22 \mathrm{~kb}$ from the transcription start site and acidosis induces a transcript, IGS28, from a locus $28 \mathrm{~kb}$, all of which in the sense direction [156,157]. These ncRNAs bind stress proteins, such as the chaperon HSP70 and the acidosis responsive von Hippel- Lindau (VHL) protein and sequester them from their site of action. DNMT1, POLD1, and RNA biogenesis factors, such as the RNA pol I and III factors RPA16 and RPA40, are other proteins that bind to these ncRNAs, further emphasising the role of these transcripts in sequestering and immobilising factors important in different pathways during stress [156,157]. Another long ncRNA, the PNCTR (pyrimidine-rich noncoding transcript), originating from $28 \mathrm{~kb}$, is proposed to sequester the RNA binding protein PTBP1 to the peri-nucleolar centre, to interfere with splicing and prevent apoptosis [158]. This stress related RNA is overexpressed in cancers and suggested to form a scaffold for the peri-nucleolar centre, a structure which is larger in cancer cells. The shorter ncRNAs from the IGS also form scaffolds in phase separated condensates, liquid-like detention centres, with sequestered mobile proteins. These condensates disrupt the nucleolar structure and reduces 47S rRNA gene transcription [159-161]. In particular, IGS16, IGS22, and IGS23 contain low-complexity RNA structures formed by repetitive cytosine/uracil (CU) or adenosine/guanine (AG) sequences, which are proposed to immobilise proteins with cationic domain and fibrillation-propensity domains [160]. The transcription of these short ncRNA initiate the formation of phase-separated aggregates, which resembles solid-like amyloid bodies, in response to thermal stress and extracellular acidosis [160]. It has been suggested that these aggregates are under the surveillance of chaperones in the protein quality control to protect against nucleolar disruption $[160,161]$.

SincRNA transcripts produced by RNA pol I have been identified from the same region in the human IGS as the stress-induced ncRNA [162]. Similar to the stress-induced ncRNAs, the sincRNAs disrupt nucleolar structure and reduce 47S gene transcription. The expression of sincRNAs is reduced by R-loops formed by RNA pol II antisense transcription at the same locus. The R-loops produced prevent RNA pol I from loading and transcribe and is regulated by the helicase Sentaxin, which facilitates RNA pol II loading at the IGS. 
R-loops are found at many location, which suggests that the whole region is transcribed and possibly is under control to reduce detrimental ncRNA transcription that can feed phase separation condensates $[163,164]$.

\subsection{Nuclear Integrity Is Important for $47 S$ rRNA Gene Transcription}

Nucleolar integrity is tightly coupled to 47S rRNA gene transcription, with many studies even showing that the assembly of nucleoli at NORs depends on active transcription [6,16-20,165-167], and a reduced transcription results in in reorganised or dispersed nucleoli $[18,19,24,165,166,168-170]$. DNA damage and inhibited 47S gene transcription lead to a reorganisation of the nucleolar structure, with the typical nucleolar caps [166,168,171,172]. A region immediately outside of the rDNA locus on all five acrocentric chromosomes harbours conserved sequences, the Distal Junction (DJ), of about $400 \mathrm{~kb}$. This region is located at the peri-nucleolar heterochromatin and anchors the rDNA [172]. It is actively transcribed by RNA pol II from at least four promoters, but the function of these transcripts is unknown. The DJ regions, perhaps their transcripts, enhance 47S rRNA gene transcription by promoting active NORs from different chromosomes to coalescence possible by promoting phase separation $[167,173]$.

Intron-derived Alu-repeat sequences in human cells, or B1 elements in mouse cells, originating from RNA pol II genes in the nucleoplasm are also important for proper nucleolar assembly, possibly by promoting coalescence of individual small nucleoli driven by phase separation. Alu-repeat sequences bind to nucleolin, NPM and fibrillarin and are required for nucleolin and NPM pre-nucleolar bodies to form larger nucleolar structures after exit from mitosis [174]. Inhibition of RNA pol II results in dispersed nucleoli and the depletion of Alu-sequences reduces 47S rRNA gene transcription as a consequence of low levels of transcription factors in these smaller nucleoli $[168,174]$.

The stress-related ncRNAs are specific for human cells, suggesting that the trigger for regulation of nucleolar integrity of nucleoli differs between species but the outcome is the same. In addition to these RNAs, further species-specific RNAs that regulate 47S rRNA gene transcription have been identified. The SLERT sno-containing RNA produced by alternative splicing from the TBRG4 locus affects RNA pol I transcription in human cells [175]. It is present in ES cells and cancer cells and increases 47S rRNA gene transcription by inhibiting the helicase DDX21. This RNA is not found in mouse cells, but regulation of the 47S rRNA gene transcription by ncRNAs occurs. Nucleolar lncRNAs have been identified from mouse brain, and the LoNa (nucleolar-specific lncRNA) binds nucleolin and fibrillarin and reduces 47S rRNA gene transcription [176].

\section{The Trigger to Switch between Different States}

Regulation of 47S rRNA gene transcription employ a network of factors and pathways, with several layers of cross-talk between the processes. Cellular states, such as proliferation, differentiation, metabolic changes and cellular stress conditions, regulate rRNA gene transcription by phosphorylation of the RNA pol I factors to change their interaction in the PIC formation [1-3,7,8]). Proliferation activates kinases in the RAS-MAPK pathway and PI3/AKT-kinase pathway as well as cyclin-CDKs (cyclin dependent kinases) during the G1 and S-phases, which phosphorylate UBF, SL1 and TIF-1A/RRN3 [177-180]. mTOR is induced in response to nutrient availability [142,143] and AMPK in response to energy starvation [146], and both pathways activate kinases that phosphorylate RNA pol I factors. In addition, cellular stress induces JNK2 [155] and PTEN [181,182] to inhibit the RNA pol machinery. These signalling pathways are most probable functioning on genes in an active chromatin state, and only stimuli requiring long-term changes in expression cause alterations of chromatin states. How long term external or internal signals are conveyed and the mechanism behind switching between chromatin states is less clear. 


\section{TTF-1 Appears to Be a Determining Factor in the Switch}

Many factors have been associated with the switch between the permissive poised state and the active state. In mouse cells, the NoRC, NuRD and CSB complexes bind to TTF- 1 and are recruited to the promoter region where they remodel the chromatin $[80,101]$. TTF-1 is in itself an important factor in the activation of 47S rRNA gene transcription by forming loops between of active genes [59-61]. The level of TTF- 1 in the nucleolus is changed upon DNA damage and oncogenic stress, when the tumour suppressor p19/14 ARF is induced and inhibits the nucleolar localisation of TTF-1 [183]. In addition, nucleolin reduces the TTF- 1 bound to the promoter [93]. The lower level of TTF-1 at the rRNA gene results in a reduced $47 \mathrm{~S}$ rRNA gene transcription $[93,183]$, possibly by reducing the ability to form TTF-1 loops and induce heterochromatin formation. TTF-1-mediated increase of 47S rRNA gene transcription occurs in insulin-stimulated adipocytes by activation of the caveolar protein Cav-1/PTRF [184,185]. Cav-1/PTRF is phosphorylated upon stimulation, localises to the nucleus, binds the TTF- 1 at the 47 rRNA gene repeat, and enhances the loop formation between the promoter and the termination of the rRNA gene [184]. In addition to TTF-1, other proteins in the rRNA gene repeat also are involved in loop formation, such as c-MYC, which is responsible for loops formed in response to transcription [186] and possibly CTCF although two inverted binding sites have not been identified [35,37,47-49]. These looping factors may compensate for each other, and siRNA silencing of TTF- 1 in HeLa cells does not reduce c-MYC recruitment [109].

How TTF-1 regulate its interactions with chromatin remodellers and affects gene expression is not fully understood. Nucleolin reduces the binding of TTF- 1 to T0, which decreases the association of TIP5 with the promoter [93] but whether this also affects CHD4 is not known. The interaction between TTF- 1 and TIP5 in NoRC is further regulated by PTM; TIP5 is acetylated by MOF and this inhibits the interaction with TTF- 1 and pRNA [187] and is deacetylated by SIRT1 upon glucose deprivation allowing for its interaction with TTF-1 to establish heterochromatin [75,81,187-189]. TTF-1 binding to CHD4 in mouse cells requires the nucleosomes at the promoter to be modified by the MLL/SET to contain histone H3K4me3 [101]. NuRD then establishes a bivalent mark consisting of histone H3K4me3 and histone $\mathrm{H} 3 \mathrm{~K} 27 \mathrm{me} 3 / \mathrm{H} 3 \mathrm{~K} 9 \mathrm{me} 3$ on nucleosomes by promoting histone $\mathrm{H} 3 \mathrm{~K} 4 \mathrm{me} 3$ formation, which affects the binding of other regulating proteins. The higher level of histone H3K4me3 counteracts the binding of SHPRH, a human protein that enhances 47S rRNA gene transcription by recruiting RNA pol I to the promoter $[190,191]$. The SHPRH is released from the promoter upon starvation or mTOR inhibition and binds instead to gene body, which correlates with a NuRD-dependent histone H3K4me3 increase at the promoter, and a simultaneous increase of histone H3K4me2 in the gene body. However, siRNA silencing of TTF-1 in HeLa cells suggests that TTF-1 is not necessary for targeting NuRD to the promoter; instead, NuRD enhances TTF-1 binding at the promoter [109]. B-WICH subunits, which counteract NuRD silencing, do not interact with TTF-1 directly, but the complex restrains the level associated with the promoter. A reduced level of TTF-1 results in an enhanced level of UBF at the promoter, suggesting that TTF-1 is involved in establishing or stabilising chromatin states at the promoter which in turn is regulated by the $\mathrm{NuRD}$ and $\mathrm{B}-\mathrm{WICH}$. This raises the question how the chromatin remodelling complexes are recruited to the promoter. B-WICH association with the promoter is independent of transcription, suggesting that the subunits interact with the chromatin at the promoter directly. In addition, WSTF is hyper-phosphorylated and stays at the rDNA throughout mitosis [192]. The WSTF also interacts with nucleolar proteins at the promoter, such CSB, DDX21 and the Myb-binding protein [107] and SIRT7 [193,194].

\section{Conclusions}

The 47S rRNA gene repeats are organised in several in different chromatin states and differently regulated to meet the need from the environment. In mammalian cells, the active genes are organised with UBF in an open chromatin state, constitutively repressed genes are heterochromatinised on methylated-DNA, and further gene repeats are in the 
less defined permissive poised state or pseudo silent state (Figure 1B). It is tempting to speculate that the UBF-organised gene repeats are regulated by PTMs of the different RNA pol transcription factors and by transcription factors, such as c-MYC; either to enhance or inhibit the formation of the PIC or change elongation rate in response to environmental conditions. During differentiation, active UBF-organised gene repeats are silenced by NoRC, which establishes a constitutively repressed nucleosomal state with the silent histone modifications $\mathrm{H} 3 \mathrm{~K} 9 \mathrm{me} 3, \mathrm{H} 4 \mathrm{~K} 20 \mathrm{me} 3$ at a DNA methylated promoter. In cancer, this repressed state is derepressed into an active state loaded with UBF, but how this switch is achieved is not known. It appears to require dysregulated oncogenes, such as c-MYC or Snail, binding at the promoter [52,53,92], but if this switch also occurs in nonmalign cells is not clear. In addition to the active and the constitutively repressed state, a permissive poised state and a pseudo-silent state have been identified, possibly providing the cell with a pool of genes that can be switched on and off to preserve homeostasis in response to metabolic states. These chromatin states appear to be heterogeneous but represents a nucleosomal state at low-methylated DNA promoters that carries bivalent histone modifications and chromatin proteins. Different chromatin remodellers and factors, such as $\mathrm{NuRD}$ or histone $\mathrm{H1}$, are associated with the permissive silent poised state and are counteracted by activating complexes, CSB [101] and B-WICH [108,109]. How these factors are recruited and regulated are poorly understood, but TTF-1 and ncRNAs appear to be involved, in addition to possible PMTs of the chromatin remodelling factors. Histone chaperones, nucleolin, NPM, and FACT, also function to regulate the chromatin state on the $47 \mathrm{~S}$ rRNA gene repeat, but it is unclear if they work to clear histones from UBF-associated active repeats, which has been suggested for nucleolin [83], or if they are involved in a switch between chromatin states on nucleosomal repeats. Which chromatin states present in each cell may be cell type dependent and rely on which factors that are expressed, WSTF in B-WICH is highly expressed in neural crest cells [195].

Several ncRNA from both the rDNA and outside of the nucleolus are involved in the regulation of $47 \mathrm{~S}$ rRNA gene transcription. These work in two ways, either by influencing the chromatin structure at the promoter or by binding proteins influencing the structure of the nucleolus (Figure 1A,B). These mechanisms are general and found in most species. Inhibited transcription results in a reorganisation of the nucleolar structure and the fibrillarin and UBF form nucleolar caps both in mouse and human cells $[167,196]$. However, the ncRNAs that changes the chromatin structure, pRNA or the PAPAS, have still to be identified in human cells. In human cells, ncRNAs are formed in response to different stress conditions to form phase separated condensates and disperse the nucleoli $[156,166,170]$, which leads to a reduce transcription. The differences between mouse and man may reflect differences in the architecture of the IGSs and the induction of ncRNAs but the ability and mechanisms to respond to environmental cues and stress is most likely the same. Nevertheless, we have identified ncRNAs that affect the accessibility of the promoter and the spacer promoter and regulate the 47S rRNA gene transcription originating from the region $30 \mathrm{~kb}$ to $40 \mathrm{~kb}$ from the transcription start site of the human IGS (Tariq and Östlund Farrants, unpublished results), indicating that also human ribosomal gene expression relies directly on chromatin changes imposed by RNA. Still many questions remain about the composition of different chromatin states and the mechanisms behind chromatin switches. Investigations has been hampered because of technical difficulties in studying repetitive gene and to distinguish between chromatin states of individual 47S rRNA gene repeats. With new imaging techniques and transcriptomics and proteomics techniques we will obtain new insights into the nature of ribosomal gene regulation.

Author Contributions: Conceptualization, A.-K.Ö.F. and K.T..; resources, A.-K.Ö.F.; writing—original draft preparation, A.-K.Ö.F.; writing—review and editing, A.-K.Ö.F. and K.T.; visualization, A.-K.Ö.F. and K.T.; supervision, A.-K.Ö.F.; project administration, A.-K.Ö.F.; funding acquisition, A.-K.Ö.F. All authors have read and agreed to the published version of the manuscript. 
Funding: This work was supported by Stockholm University and The Swedish Cancer Society (grant number $190453 \mathrm{Pj}$ ).

Institutional Review Board Statement: Not applicable.

Informed Consent Statement: Not applicable.

Data Availability Statement: Not applicable.

Conflicts of Interest: The authors declare no conflict of interest.

\section{References}

1. Kusnadi, E.P.; Hannan, K.M.; Hicks, R.J.; Hannan, R.D.; Pearson, R.B.; Kang, J. Regulation of rDNA transcription in response to growth factors, nutrient and energy. Gene 2015, 556, 27-34. [CrossRef] [PubMed]

2. Ferreira, R.; Schneekloth, J.S., Jr.; Panov, K.I.; Hannan, K.M.; Hannan, R.D. Targeting the RNA Polymerase I Transcription for Cancer Therapy Comes of Age. Cells 2020, 9, 266. [CrossRef]

3. Gaviraghi, M.; Vivori, C.; Tonon, G. How Cancer Exploits Ribosomal RNA Biogenesis: A Journey beyond the Boundaries of rRNA Transcription. Cells 2019, 17, 1098. [CrossRef] [PubMed]

4. Sanij, E.; Hannan, K.M.; Xuan, J.; Yan, S.; Ahern, J.E.; Trigos, A.S.; Brajanovski, N.; Son, J.; Chan, K.T.; Kondrashova, O.; et al. CX-5461 activates the DNA damage response and demonstrates therapeutic efficacy in high-grade serous ovarian cancer. Nat. Commun. 2020, 11, 2641. [CrossRef]

5. Low, J.Y.; Sirajuddin, P.; Moubarek, M.; Agarwal, S.; Rege, A.; Guner, G.; Liu, H.; Yang, Z.; De Marzo, A.M.; Bieberich, C.; et al. Effective targeting of RNA polymerase I in treatment-resistant prostate cancer. Prostate 2019, 79, 1837-1851. [CrossRef]

6. Catez, F.; Dalla Venezia, N.; Marcel, V.; Zorbas, C.; Lafontaine, D.L.J.; Diaz, J.J. Ribosome biogenesis: An emerging druggable pathway for cancer therapeutics. Biochem. Pharmacol. 2019, 159, 74-81. [CrossRef]

7. Sharifi, S.; Bierhoff, H. Regulation of RNA Polymerase I Transcription in Development, Disease, and Aging. Annu. Rev. Biochem. 2018, 87, 51-73. [CrossRef]

8. Piazzi, M.; Bavelloni, A.; Gallo, A.; Faenza, I.; Blalock, W.L. Signal Transduction in Ribosome hamdaneBiogenesis: A Recipe to Avoid Disaster. Int. J. Mol. Sci. 2019, 20, 2718. [CrossRef] [PubMed]

9. Hu, H.; Li, X. Transcriptional regulation in eukaryotic ribosomal protein genes. Genomics 2007, 90, 421-423. [CrossRef] [PubMed]

10. Guimaraes, J.C.; Zavolan, M. Patterns of ribosomal protein expression specify normal and malignant human cells. Genome Biol. 2016, 17, 236. [CrossRef] [PubMed]

11. Li, X.; Zheng, Y.; Hu, H.; Li, X. Integrative analyses shed new light on human ribosomal protein gene regulation. Sci. Rep. 2016, 6, 28619. [CrossRef]

12. Simsek, D.; Tiu, G.C.; Flynn, R.A.; Byeon, G.W.; Leppek, K.; Xu, A.F.; Chang, H.Y.; Barna, M. The Mammalian Ribo-interactome Reveals Ribosome Functional Diversity and Heterogeneity. Cell 2017, 169, 1051-1065. [CrossRef]

13. Genuth, N.R.; Barna, M. The Discovery of Ribosome Heterogeneity and Its Implications for Gene Regulation and Organismal Life. Mol. Cell 2018, 71, 364-374. [CrossRef] [PubMed]

14. Hernandez-Verdun, D. Assembly and disassembly of the nucleolus during the cell cycle. Nucleus 2011, 2, 189-194. [CrossRef] [PubMed]

15. Moss, T.; Langlois, F.; Gagnon-Kugler, T.; Stefanovsky, V. A housekeeper with power of attorney: The rRNA genes in ribosome biogenesis. Cell. Mol. Life Sci. 2007, 64, 29-49. [CrossRef] [PubMed]

16. Grob, A.; Colleran, C.; McStay, B. Construction of synthetic nucleoli in human cells reveals how a major functional nuclear domain is formed and propagated through cell division. Genes Dev. 2014, 28, 220-230. [CrossRef] [PubMed]

17. Farley, K.I.; Surovtseva, Y.; Merkel, J.; Baserga, S.J. Determinants of mammalian nucleolar architecture. Chromosoma 2015, 124, 323-331. [CrossRef] [PubMed]

18. McStay, B. Nucleolar organizer regions: Genomic 'dark matter' requiring illumination. Genes Dev. 2016, 30, 1598-1610. [CrossRef]

19. Cerqueira, A.V.; Lemos, B. Ribosomal DNA and the Nucleolus as Keystones of Nuclear Architecture, Organization, and Function. Trends Genet. 2019, 35, 710-723. [CrossRef]

20. Rodriguez-Corona, U.; Sobol, M.; Rodriguez-Zapata, L.C.; Hozak, P.; Castano, E. Fibrillarin from Archaea to human. Biol Cell. 2015, 107, 159-174. [CrossRef]

21. Durut, N.; Sáez-Vásquez, J. Nucleolin: Dual roles in rDNA chromatin transcription. Gene 2015, 556, 7-12. [CrossRef]

22. Scott, D.D.; Oeffinger, M. Nucleolin and nucleophosmin: Nucleolar proteins with multiple functions in DNA repair. Biochem. Cell Biol. 2016, 94, 419-432. [CrossRef]

23. López, D.J.; Rodríguez, J.A.; Bañuelos, S. Nucleophosmin, a multifunctional nucleolar organizer with a role in DNA repair. Biochim. Biophys Acta Proteins Proteom. 2020, 1868, 140532. [CrossRef]

24. Mangan, H.; Gailín, M.Ó.; McStay, B. Integrating the genomic architecture of human nucleolar organizer regions with the biophysical properties of nucleoli. FEBS J. 2017, 284, 3977-3985. [CrossRef] [PubMed]

25. Yao, R.W.; Xu, G.; Wang, Y.; Shan, L.; Luan, P.F.; Wang, Y.; Wu, M.; Yang, L.Z.; Xing, Y.H.; Yang, L.; et al. Nascent Pre-rRNA Sorting via Phase Separation Drives the Assembly of Dense Fibrillar Components in the Human Nucleolus. Mol. Cell 2019, 76, 767-783. [CrossRef] 
26. Sen Gupta, A.; Joshi, G.; Pawar, S.; Sengupta, K. Nucleolin modulates compartmentalization and dynamics of histone 2B-ECFP in the nucleolus. Nucleus 2018, 9, 350-367. [CrossRef] [PubMed]

27. Frottin, F.; Schueder, F.; Tiwary, S.; Gupta, R.; Körner, R.; Schlichthaerle, T.; Cox, J.; Jungmann, R.; Hartl, F.U.; Hipp, M.S. The nucleolus functions as a phase-separated protein quality control compartment. Science 2019, 365, 342-347. [CrossRef] [PubMed]

28. Salvetti, A.; Greco, A. Viruses and the nucleolus: The fatal attraction. Biochim. Biophys Acta. 2014, 1842, 840-847. [CrossRef]

29. Schöfer, C.; Weipoltshammer, K. Nucleolus and chromatin. Histochem. Cell Biol. 2018, 150, 209-225. [CrossRef] [PubMed]

30. Bersaglieri, C.; Santoro, R. Genome Organization in and around the Nucleolus. Cells 2019, 8, 579. [CrossRef] [PubMed]

31. Moss, T.; Mars, J.C.; Tremblay, M.G.; Sabourin-Felix, M. The chromatin landscape of the ribosomal RNA genes in mouse and human. Chromosome Res. 2019, 27, 31-40. [CrossRef] [PubMed]

32. Sanij, E.; Poortinga, G.; Sharkey, K.; Hung, S.; Holloway, T.P.; Quin, J.; Robb, E.; Wong, L.H.; Thomas, W.G.; Stefanovsky, V.; et al. UBF levels determine the number of active ribosomal RNA genes in mammals. J. Cell Biol. 2008, 183, 1259-1274. [CrossRef]

33. Zentner, G.E.; Saiakhova, A.; Manaenkov, P.; Adams, M.D.; Scacheri, P.C. Integrative genomic analysis of human ribosomal DNA. Nucleic Acids Res. 2011, 39, 4949-4960. [CrossRef]

34. Hamdane, N.; Stefanovsky, V.Y.; Tremblay, M.G.; Németh, A.; Paquet, E.; Lessard, F.; Sanij, E.; Hannan, R.; Moss, T. Conditional inactivation of Upstream Binding Factor reveals its epigenetic functions and the existence of a somatic nucleolar precursor body. PLoS Genet. 2014, 10, e1004505. [CrossRef] [PubMed]

35. Herdman, C.; Mars, J.C.; Stefanovsky, V.Y.; Tremblay, M.G.; Sabourin-Felix, M.; Lindsay, H.; Robinson, M.D.; Moss, T. A unique enhancer boundary complex on the mouse ribosomal RNA genes persists after loss of Rrn3 or UBF and the inactivation of RNA polymerase I transcription. PLoS Genet. 2017, 13, e1006899. [CrossRef] [PubMed]

36. Hamdane, N.; Tremblay, M.G.; Dillinger, S.; Stefanovsky, V.Y.; Németh, A.; Moss, T. Disruption of the UBF gene induces aberrant somatic nucleolar bodies and disrupts embryo nucleolar precursor bodies. Gene 2017, 612, 5-11. [CrossRef]

37. Mars, J.C.; Sabourin-Felix, M.; Tremblay, M.G.; Moss, T. A Deconvolution Protocol for ChIP-Seq Reveals Analogous Enhancer Structures on the Mouse and Human Ribosomal RNA Genes. G3 (Bethesda) 2018, 8, 303-314. [CrossRef]

38. Stefanovsky, V.Y.; Bazett-Jones, D.P.; Pelletier, G.; Moss, T. The DNA supercoiling architecture induced by the transcription factor xUBF requires three of its five HMG-boxes. Nucleic Acids Res. 1996, 24, 3208-3215. [CrossRef]

39. Tuan, J.C.; Zhai, W.; Comai, L. Recruitment of TATA-binding protein-TAFI complex SL1 to the human ribosomal DNA promoter is mediated by the carboxy-terminal activation domain of upstream binding factor (UBF) and is regulated by UBF phosphorylation. Mol. Cell. Biol. 1999, 19, 2872-2879. [CrossRef]

40. Friedrich, J.K.; Panov, K.I.; Cabart, P.; Russell, J.; Zomerdijk, J.C. TBP-TAF complex SL1 directs RNA polymerase I pre-initiation complex formation and stabilizes upstream binding factor at the rDNA promoter. J. Biol. Chem. 2005, 280, 29551-29558. [CrossRef]

41. Panov, K.I.; Friedrich, J.K.; Russell, J.; Zomerdijk, J.C. UBF activates RNA polymerase I transcription by stimulating promoter escape. EMBO J. 2006, 25, 3310-3322. [CrossRef]

42. Sanij, E.; Hannan, R.D. The role of UBF in regulating the structure and dynamics of transcriptionally active rDNA chromatin. Epigenetics 2009, 4, 374-382. [CrossRef] [PubMed]

43. Kuhn, A.; Grummt, I. A novel promoter in the mouse rDNA spacer is active in vivo and in vitro. EMBO J. 1987, 6, 3487-3492. [CrossRef] [PubMed]

44. Paalman, M.H.; Henderson, S.L.; Sollner-Webb, B. Stimulation of the mouse rRNA gene promoter by a distal spacer promoter. Mol. Cell. Biol. 1995, 15, 4648-4656. [CrossRef] [PubMed]

45. Mayer, C.; Schmitz, K.M.; Li, J.; Grummt, I.; Santoro, R. Intergenic transcripts regulate the epigenetic state of rRNA genes. Mol. Cell 2006, 22, 351-361. [CrossRef] [PubMed]

46. Mayer, C.; Neubert, M.; Grummt, I. The structure of NoRC-associated RNA is crucial for targeting the chromatin remodelling complex NoRC to the nucleolus. EMBO Rep. 2008, 9, 774-780. [CrossRef]

47. Van de Nobelen, S.; Rosa-Garrido, M.; Leers, J.; Heath, H.; Soochit, W.; Joosen, L.; Jonkers, I.; Demmers, J.; Van der Reijden, M.; Torrano, V.; et al. CTCF regulates the local epigenetic state of ribosomal DNA repeats. Epigenet. Chromatin. 2010, 3, 19. [CrossRef]

48. Huang, K.; Jia, J.; Wu, C.; Yao, M.; Li, M.; Jin, J.; Jiang, C.; Cai, Y.; Pei, D.; Pan, G.; et al. Ribosomal RNA gene transcription mediated by the master genome regulator protein CCCTC-binding factor (CTCF) is negatively regulated by the condensin complex. J. Biol. Chem. 2013, 288, 26067-26077. [CrossRef]

49. Yu, F.; Shen, X.; Fan, L.; Yu, Z. Analysis of histone modifications at human ribosomal DNA in liver cancer cell. Sci. Rep. 2015, 5, 18100. [CrossRef]

50. Sadova, A.A.; Kupriyanova, N.S.; Pavlova, G.V. Mapping and Quantification of Non-Coding RNA Originating from the rDNA in Human Glioma Cells. Cancers 2020, 12, 2090. [CrossRef]

51. Goodfellow, S.J.; Zomerdijk, J.C. Basic mechanisms in RNA polymerase I transcription of the ribosomal RNA genes. Subcell Biochem. 2013, 61, 211-236. [CrossRef] [PubMed]

52. Hung, S.S.; Lesmana, A.; Peck, A.; Lee, R.; Tchoubrieva, E.; Hannan, K.M.; Lin, J.; Sheppard, K.E.; Jastrzebski, K.; Quinn, L.M.; et al. Cell cycle and growth stimuli regulate different steps of RNA polymerase I transcription. Gene 2017, 612, 36-48. [CrossRef] [PubMed]

53. Diesch, J.; Bywater, M.J.; Sanij, E.; Cameron, D.P.; Schierding, W.; Brajanovski, N.; Son, J.; Sornkom, J.; Hein, N.; Evers, M.; et al. Changes in long-range rDNA-genomic interactions associate with altered RNA polymerase II gene programs during malignant transformation. Commun. Biol. 2019, 2, 39. [CrossRef] [PubMed] 
54. Stefanovsky, V.; Langlois, F.; Gagnon-Kugler, T.; Rothblum, L.I.; Moss, T. Growth factor signaling regulates elongation of RNA polymerase I transcription in mammals via UBF phosphorylation and r-chromatin remodelling. Mol Cell. 2006, 21, 629-639. [CrossRef] [PubMed]

55. Son, J.; Hannan, K.M.; Poortinga, G.; Hein, N.; Cameron, D.P.; Ganley, A.R.D.; Sheppard, K.E.; Pearson, R.B.; Hannan, R.D.; Sanij, E. rDNA Chromatin Activity Status as a Biomarker of Sensitivity to the RNA Polymerase I Transcription Inhibitor CX-5461. Front. Cell Dev. Biol. 2020, 8, 568. [CrossRef]

56. Németh, A.; Strohner, R.; Grummt, I.; Längst, G. The chromatin remodeling complex NoRC and TTF-I cooperate in the regulation of the mammalian rRNA genes in vivo. Nucleic Acids Res. 2004, 32, 4091-4099. [CrossRef]

57. López-estraño, C.; Schvartzman, J.B.; Krimer, D.B.; Hernández, P. Co-localization of polar replication fork barriers and rRNA transcription terminators in mouse rDNA. J. Mol. Biol. 1998, 277, 249-256. [CrossRef]

58. Akamatsu, Y.; Kobayashi, T. The Human RNA Polymerase I Transcription Terminator Complex Acts as a Replication Fork Barrier That Coordinates the Progress of Replication with rRNA Transcription Activity. Mol. Cell. Biol. 2015, 35, 1871-1881. [CrossRef]

59. Németh, A.; Guibert, S.; Tiwari, V.K.; Ohlsson, R.; Längst, G. Epigenetic regulation of TTF-I-mediated promoterterminator interactions of rRNA genes. EMBO J. 2008, 27, 1255-1265. [CrossRef]

60. Németh, A.; Längst, G. Genome organization in and around the nucleolus. Trends Genet. 2011, 27, 149-156. [CrossRef]

61. Denissov, S.; Lessard, F.; Mayer, C.; Stefanovsky, V.; Van Driel, M.; Grummt, I.; Moss, T.; Stunnenberg, H.G. A model for the topology of active ribosomal RNA genes. EMBO Rep. 2011, 12, 231-237. [CrossRef] [PubMed]

62. Maiser, A.; Dillinger, S.; Längst, G.; Schermelleh, L.; Leonhardt, H.; Németh, A. Super-resolution in situ analysis of active ribosomal DNA chromatin organization in the nucleolus. Sci. Rep. 2020, 10, 7462. [CrossRef]

63. Ghirlando, R.; Felsenfeld, G. CTCF: Making the right connections. Genes Dev. 2016, 30, 881-891. [CrossRef]

64. Pelletier, G.; Stefanovsky, V.Y.; Faubladier, M.; Hirschler-Laszkiewicz, I.; Savard, J.; Rothblum, L.I.; Côté, J.; Moss, T. Competitive recruitment of CBP and Rb-HDAC regulates UBF acetylation and ribosomal transcription. Mol. Cell 2000, 6, 1059-1066. [CrossRef]

65. Hirschler-Laszkiewicz, I.; Cavanaugh, A.; Hu, Q.; Catania, J.; Avantaggiati, M.L.; Rothblum, L.I. The role of acetylation in rDNA transcription. Nucleic Acids Res. 2001, 29, 4114-4124. [CrossRef]

66. Meraner, J.; Lechner, M.; Loidl, A.; Goralik-Schramel, M.; Voit, R.; Grummt, I.; Loidl, P. Acetylation of UBF changes during the cell cycle and regulates the interaction of UBF with RNA polymerase I. Nucleic Acids Res. 2006, 34, 1798-1806. [CrossRef] [PubMed]

67. Lee, J.; Hwang, Y.J.; Boo, J.H.; Han, D.; Kwon, O.K.; Todorova, K.; Kowall, N.W.; Kim, Y.; Ryu, H. Dysregulation of upstream binding factor-1 acetylation at K352 is linked to impaired ribosomal DNA transcription in Huntington's disease. Cell Death Differ. 2011, 18, 1726-1735. [CrossRef]

68. Peng, Q.; Wu, J.; Zhang, Y.; Liu, Y.; Kong, R.; Hu, L.; Du, X.; Ke, Y. 1A6/DRIM, a novel t-UTP, activates RNA polymerase I transcription and promotes cell proliferation. PLoS ONE 2010, 5, e14244. [CrossRef] [PubMed]

69. Kong, R.; Zhang, L.; Hu, L.; Peng, Q.; Han, W.; Du, X.; Ke, Y. hALP, a novel transcriptional U three protein (t-UTP), activates RNA polymerase I transcription by binding and acetylating the upstream binding factor (UBF). J. Biol. Chem. 2011, 286, 7139-7148. [CrossRef]

70. Kresoja-Rakic, J.; Santoro, R. Nucleolus and rRNA Gene Chromatin in Early Embryo Development. Trends Genet. 2019, 35, 868-879. [CrossRef]

71. Romanova, L.; Korobova, F.; Noniashvilli, E.; Dyban, A.; Zatsepina, O. High resolution mapping of ribosomal DNA in early mouse embryos by fluorescence in situ hybridization. Biol. Reprod. 2006, 74, 807-815. [CrossRef] [PubMed]

72. Grummt, I.; Längst, G. Epigenetic control of RNA polymerase I transcription in mammalian cells. Biochim. Biophys. Acta 2013, 1829, 393-404. [CrossRef]

73. Savić, N.; Bär, D.; Leone, S.; Frommel, S.C.; Weber, F.A.; Vollenweider, E.; Ferrari, E.; Ziegler, U.; Kaech, A.; Shakhova, O.; et al lncRNA maturation to initiate heterochromatin formation in the nucleolus is required for exit from pluripotency in ESCs. Cell Stem Cell 2014, 15, 720-734. [CrossRef] [PubMed]

74. Santoro, R.; Grummt, I. Molecular mechanisms mediating methylation-dependent silencing of ribosomal gene transcription. Mol. Cell 2001, 8, 719-725. [CrossRef]

75. Schmitz, K.M.; Mayer, C.; Postepska, A.; Grummt, I. Interaction of noncoding RNA with the rDNA promoter mediates recruitment of DNMT3b and silencing of rRNA genes. Genes Dev. 2010, 24, 2264-2269. [CrossRef]

76. Strohner, R.; Németh, A.; Nightingale, K.P.; Grummt, I.; Becker, P.B.; Längst, G. Recruitment of the nucleolar remodeling complex NoRC establishes ribosomal DNA silencing in chromatin. Mol. Cell. Biol. 2004, 24, 1791-1798. [CrossRef]

77. Strohner, R.; Nemeth, A.; Jansa, P.; Hofmann-Rohrer, U.; Santoro, R.; Längst, G.; Grummt, I. NoRC-a novel member of mammalian ISWI-containing chromatin remodelling machines. EMBO J. 2001, 20, 4892-4900. [CrossRef]

78. Zhou, Y.; Grummt, I. The PHD finger/bromodomain of NoRC interacts with acetylated histone H4K16 and is sufficient for rDNA silencing. Curr. Biol. 2005, 15, 1434-1438. [CrossRef]

79. Tallant, C.; Valentini, E.; Fedorov, O.; Overvoorde, L.; Ferguson, F.M.; Filippakopoulos, P.; Svergun, D.I.; Knapp, S.; Ciulli, A. Molecular basis of histone tail recognition by human TIP5 PHD finger and bromodomain of the chromatin remodeling complex NoRC. Structure 2015, 23, 80-92. [CrossRef]

80. Li, J.; Längst, G.; Grummt, I. NoRC-dependent nucleosome positioning silences rRNA genes. EMBO J. 2006, $25,5735-5741$. [CrossRef] 
81. Manelyte, L.; Strohner, R.; Gross, T.; Längst, G. Chromatin targeting signals, nucleosome positioning mechanism and non-coding RNA-mediated regulation of the chromatin. PLoS Genet. 2014, 10, e1004157. [CrossRef]

82. Bierhoff, H.; Dammert, M.A.; Brocks, D.; Dambacher, S.; Schotta, G.; Grummt, I. Quiescence-induced LncRNAs trigger H4K20 trimethylation and transcriptional silencing. Mol. Cell 2014, 54, 675-682. [CrossRef]

83. Cong, R.; Das, S.; Douet, J.; Wong, J.; Buschbeck, M.; Mongelard, F.; Bouvet, P. macroH2A1 histone variant represses rDNA transcription. Nucleic Acids Res. 2014, 42, 181-192. [CrossRef] [PubMed]

84. Kalashnikova, A.A.; Winkler, D.D.; McBryant, S.J.; Henderson, R.K.; Herman, J.A.; DeLuca, J.G.; Luger, K.; Prenni, J.E.; Hansen, J.C. Linker histone H1.0 interacts with an extensive network of proteins found in the nucleolus. Nucleic Acids Res. 2013, 41, 4026-4035. [CrossRef]

85. Szerlong, H.J.; Herman, J.A.; Krause, C.M.; DeLuca, J.G.; Skoultchi, A.; Winger, Q.A.; Prenni, J.E.; Hansen, J.C. Proteomic characterization of the nucleolar linker histone H1 interaction network. J. Mol. Biol. 2015, 427, 2056-2071. [CrossRef]

86. Mayor, R.; Izquierdo-Bouldstridge, A.; Millan-Arino, L.; Bustillos, A.; Sampaio, C.; Luque, N.; Jordan, A. Genome distribution of replication-independent histone $\mathrm{H} 1$ variants shows $\mathrm{H} 1.0$ associated with nucleolar domains and H1X with RNA polymerase II-enriched regions. J. Biol. Chem. 2015, 290, 7474-7491. [CrossRef]

87. Chen, J.; Teo, B.H.D.; Cai, Y.; Wee, S.Y.K.; Lu, J. The linker histone H1.2 is a novel component of the nucleolar organizer regions. J. Biol. Chem. 2018, 293, 2358-2369. [CrossRef]

88. Zheng, Y.; John, S.; Pesavento, J.J.; Schultz-Norton, J.R.; Schiltz, R.L.; Baek, S.; Nardulli, A.M.; Hager, G.L.; Kelleher, N.L.; Mizzen, C.A. Histone $\mathrm{H} 1$ phosphorylation is associated with transcription by RNA polymerases I and II. J. Cell Biol. 2010, 189, 407-415. [CrossRef]

89. Khan, A.; Giri, S.; Wang, Y.; Chakraborty, A.; Ghosh, A.K.; Anantharaman, A.; Aggarwal, V.; Sathyan, K.M.; Ha, T.; Prasanth, K.V.; et al. BEND3 represses rDNA transcription by stabilizing a NoRC component via USP21 deubiquitinase. Proc. Natl. Acad. Sci. USA 2015, 112, 8338-8343. [CrossRef]

90. Rajarajacholan, U.K.; Thalappilly, S.; Riabowol, K. ING1 regulates rRNA levels by altering nucleolar chromatin structure and mTOR localization. Nucleic Acids Res. 2017, 45, 1776-1792. [CrossRef]

91. Ali, S.A.; Dobson, J.R.; Lian, J.B.; Stein, J.L.; Van Wijnen, A.J.; Zaidi, S.K.; Stein, G.S. A RUNX2-HDAC1 co-repressor complex regulates rRNA gene expression by modulating UBF acetylation. J. Cell Sci. 2012, 125, 2732-2739. [CrossRef]

92. Prakash, V.; Carson, B.B.; Feenstra, J.M.; Dass, R.A.; Sekyrova, P.; Hoshino, A.; Petersen, J.; Guo, Y.; Parks, M.M.; Kurylo, C.M.; et al. Ribosome biogenesis during cell cycle arrest fuels EMT in development and disease. Nat. Commun. 2019, 10, 2110. [CrossRef]

93. Cong, R.; Das, S.; Ugrinova, I.; Kumar, S.; Mongelard, F.; Wong, J.; Bouvet, P. Interaction of nucleolin with ribosomal RNA genes and its role in RNA polymerase I transcription. Nucleic Acids Res. 2012, 40, 9441-9454. [CrossRef]

94. Angelov, D.; Bondarenko, V.A.; Almagro, S.; Menoni, H.; Mongélard, F.; Hans, F.; Mietton, F.; Studitsky, V.M.; Hamiche, A.; Dimitrov, S.; et al. Nucleolin is a histone chaperone with FACT-like activity and assists remodeling of nucleosomes. $E M B O J$. 2006, 25, 1669-1679. [CrossRef]

95. Kobayashi, J.; Fujimoto, H.; Sato, J.; Hayashi, I.; Burma, S.; Matsuura, S.; Chen, D.J.; Komatsu, K. Nucleolin participates in DNA double-strand break-induced damage response through MDC1-dependent pathway. PLoS ONE 2012, 7, e49245. [CrossRef]

96. Birch, J.L.; Tan, B.C.; Panov, K.I.; Panova, T.B.; Andersen, J.S.; Owen-Hughes, T.A.; Russell, J.; Lee, S.C.; Zomerdijk, J.C. FACT facilitates chromatin transcription by RNA polymerases I and III. EMBO J. 2009, 28, 854-865. [CrossRef]

97. Tessarz, P.; Santos-Rosa, H.; Robson, S.C. Glutamine methylation in histone H2A is an RNA-polymerase-I-dedicated modification. Nature 2014, 505, 564-568. [CrossRef]

98. Hisaoka, M.; Ueshima, S.; Murano, K.; Nagata, K.; Okuwaki, M. Regulation of nucleolar chromatin by B23/nucleophosmin jointly depends upon its RNA binding activity and transcription factor UBF. Mol. Cell. Biol. 2010, 30, 4952-4964. [CrossRef]

99. Murano, K.; Okuwaki, M.; Hisaoka, M.; Nagata, K. Transcription regulation of the rRNA gene by a multifunctional nucleolar protein, B23/nucleophosmin, through its histone chaperone activity. Mol. Cell. Biol. 2008, 28, 3114-3126. [CrossRef]

100. Kowalski, A. Nuclear and nucleolar activity of linker histone variant H1.0. Cell. Mol. Biol. Lett. 2016, 21, 15. [CrossRef]

101. Xie, W.; Ling, T.; Zhou, Y.; Feng, W.; Zhu, Q.; Stunnenberg, H.G.; Grummt, I.; Tao, W. The chromatin remodeling complex NuRD establishes the poised state of rRNA genes characterized by bivalent histone modifications and altered nucleosome positions. Proc. Natl. Acad. Sci. USA 2012, 109, 8161-8166. [CrossRef]

102. Yuan, X.; Feng, W.; Imhof, A.; Grummt, I.; Zhou, Y. Activation of RNA polymerase I transcription by cockayne syndrome group B protein and histone methyltransferase G9a. Mol. Cell 2007, 27, 585-595. [CrossRef]

103. Ling, T.; Xie, W.; Luo, M.; Shen, M.; Zhu, Q.; Zong, L.; Zhou, T.; Gu, J.; Lu, Z.; Zhang, F.; et al. CHD4/NuRD maintains demethylation state of rDNA promoters through inhibiting the expression of the rDNA methyltransferase recruiter TIP5. Biochem. Biophys. Res. Commun. 2013, 437, 101-107. [CrossRef]

104. Shen, M.; Zhou, T.; Xie, W.; Ling, T.; Zhu, Q.; Zong, L.; Lyu, G.; Gao, Q.; Zhang, F.; Tao, W. The chromatin remodeling factor CSB recruits histone acetyltransferase PCAF to rRNA gene promoters in active state for transcription initiation. PLoS ONE 2013, 8 , e62668. [CrossRef]

105. Okur, M.N.; Lee, J.H.; Osmani, W.; Kimura, R.; Demarest, T.G.; Croteau, D.L.; Bohr, V.A. Cockayne syndrome group A and B proteins function in rRNA transcription through nucleolin regulation. Nucleic Acids Res. 2020, 48, 2473-2485. [CrossRef] 
106. Percipalle, P.; Fomproix, N.; Cavellán, E.; Voit, R.; Reimer, G.; Krüger, T.; Thyberg, J.; Scheer, U.; Grummt, I.; Farrants, A.K. The chromatin remodelling complex WSTF-SNF2h interacts with nuclear myosin 1 and has a role in RNA polymerase I transcription. EMBO Rep. 2006, 7, 525-530. [CrossRef]

107. Cavellán, E.; Asp, P.; Percipalle, P.; Farrants, A.K. The WSTF-SNF2h chromatin remodeling complex interacts with several nuclear proteins in transcription. J. Biol. Chem. 2006, 281, 16264-16271. [CrossRef]

108. Vintermist, A.; Böhm, S.; Sadeghifar, F.; Louvet, E.; Mansén, A.; Percipalle, P.; Ostlund Farrants, A.K. The chromatin remodelling complex B-WICH changes the chromatin structure and recruits histone acetyl-transferases to active rRNA genes. PLoS ONE 2011, 6, e19184. [CrossRef]

109. Rolicka, A.; Guo, Y.; Gañez Zapater, A.; Tariq, K.; Quin, J.; Vintermist, A.; Sadeghifar, F.; Arsenian-Henriksson, M.; Östlund Farrants, A.K. The chromatin-remodeling complexes B-WICH and NuRD regulate ribosomal transcription in response to glucose. FASEB J. 2020, 34, 10818-10834. [CrossRef] [PubMed]

110. Arabi, A.; Wu, S.; Ridderstråle, K.; Bierhoff, H.; Shiue, C.; Fatyol, K.; Fahlén, S.; Hydbring, P.; Söderberg, O.; Grummt, I.; et al. c-Myc associates with ribosomal DNA and activates RNA polymerase I transcription. Nat. Cell Biol. 2005, 7, 303-310. [CrossRef]

111. Grandori, C.; Gomez-Roman, N.; Felton-Edkins, Z.A.; Ngouenet, C.; Galloway, D.A.; Eisenman, R.N.; White, R.J. c-Myc binds to human ribosomal DNA and stimulates transcription of rRNA genes by RNA polymerase I. Nat. Cell Biol. 2005, 7, 311-318. [CrossRef]

112. Li, Z.; Hann, S.R. Nucleophosmin is essential for c-Myc nucleolar localization and c-Myc-mediated rDNA transcription. Oncogene 2013, 32, 1988-1994. [CrossRef]

113. McMahon, S.B.; Wood, M.A.; Cole, M.D. The essential cofactor TRRAP recruits the histone acetyltransferase hGCN5 to c-Myc. Mol. Cell. Biol. 2000, 20, 556-562. [CrossRef]

114. Von Walden, F.; Casagrande, V.; Östlund Farrants, A.K.; Nader, G.A. Mechanical loading induces the expression of a Pol I regulon at the onset of skeletal muscle hypertrophy. Am. J. Physiol. Cell Physiol. 2012, 302, C1523-C1530. [CrossRef]

115. Sadeghifar, F.; Böhm, S.; Vintermist, A.; Östlund Farrants, A.K. The B-WICH chromatin-remodelling complex regulates RNA polymerase III transcription by promoting Max-dependent c-Myc binding. Nucleic Acids Res. 2015, 43, 4477-4490. [CrossRef]

116. Poortinga, G.; Wall, M.; Sanij, E.; Siwicki, K.; Ellul, J.; Brown, D.; Holloway, T.P.; Hannan, R.D.; McArthur, G.A. c-MYC coordinately regulates ribosomal gene chromatin remodeling and Pol I availability during granulocyte differentiation. Nucleic Acids Res. 2011, 39, 3267-3281. [CrossRef]

117. Peng, Y.; Wang, Z.; Wang, Z.; Yu, F.; Li, J.; Wong, J. SUMOylation down-regulates rDNA transcription by repressing expression of upstream-binding factor and proto-oncogene c-Myc. J. Biol. Chem. 2019, 294, 19155-19166. [CrossRef]

118. Dunn, S.; Lombardi, O.; Cowling, V.H. c-Myc co-ordinates mRNA cap methylation and ribosomal RNA production. Biochem. J. 2017, 474, 377-384. [CrossRef]

119. Poortinga, G.; Quinn, L.M.; Hannan, R.D. Targeting RNA polymerase I to treat MYC-driven cancer. Oncogene 2015, $34,403-412$. [CrossRef]

120. Sanij, E.; Diesch, J.; Lesmana, A.; Poortinga, G.; Hein, N.; Lidgerwood, G.; Cameron, D.P.; Ellul, J.; Goodall, G.J.; Wong, L.H.; et al. A novel role for the Pol I transcription factor UBTF in maintaining genome stability through the regulation of highly transcribed Pol II genes. Genome Res. 2015, 25, 201-212. [CrossRef]

121. Trinh, D.A.; Shirakawa, R.; Kimura, T.; Sakata, N.; Goto, K.; Horiuchi, H. Inhibitor of Growth 4 (ING4) is a positive regulator of rRNA synthesis. Sci. Rep. 2019, 9, 17235. [CrossRef]

122. Izumikawa, K.; Ishikawa, H.; Yoshikawa, H.; Fujiyama, S.; Watanabe, A.; Aburatani, H.; Tachikawa, H.; Hayano, T. LYAR potentiates rRNA synthesis by recruiting BRD2/4 and the MYST-type acetyltransferase KAT7 to rDNA. Nucleic Acids Res. 2019, 47, 10357-10372. [CrossRef]

123. Muth, V.; Nadaud, S.; Grummt, I.; Voit, R. Acetylation of TAFI68, a subunit of TIF-IB/ SL1, activates RNA polymerase I transcription. EMBO J. 2001, 20, 1353-1362. [CrossRef]

124. Voit, R.; Seiler, J.; Grummt, I. Cooperative action of Cdk1/cyclin B and SIRT1 is required for mitotic repression of rRNA synthesis. PLoS Genet. 2015, 11, e1005246. [CrossRef]

125. Blank, M.F.; Grummt, I. The seven faces of SIRT7. Transcription 2017, 8, 67-74. [CrossRef] [PubMed]

126. Ford, E.; Voit, R.; Liszt, G.; Magin, C.; Grummt, I.; Guarente, L. Mammalian Sir2 homolog SIRT7 is an activator of RNA polymerase I transcription. Genes Dev. 2006, 20, 1075-1080. [CrossRef]

127. Grob, A.; Roussel, P.; Wright, J.E.; McStay, B.; Hernandez-Verdun, D.; Sirri, V. Involvement of SIRT7 in resumption of rDNA transcription at the exit from mitosis. J. Cell Sci. 2009, 122, 489-498. [CrossRef]

128. Chen, S.; Seiler, J.; Santiago-Reichelt, M.; Felbel, K.; Grummt, I.; Voit, R. Repression of RNA polymerase I upon stress is caused by inhibition of RNA-dependent deacetylation of PAF53 by SIRT7. Mol. Cell 2013, 52, 303-313. [CrossRef]

129. Song, C.; Hotz-Wagenblatt, A.; Voit, R.; Grummt, I. SIRT7 and the DEAD-box helicase DDX21 cooperate to resolve genomic R loops and safeguard genome stability. Genes Dev. 2017, 31, 1370-1381. [CrossRef]

130. Chen, S.; Blank, M.F.; Iyer, A.; Huang, B.; Wang, L.; Grummt, I.; Voit, R. SIRT7-dependent deacetlyation of the U3-55k protein controls pre-rRNA processing. Nat. Commun. 2016, 7, 10734. [CrossRef]

131. Sirri, V.; Grob, A.; Berthelet, J.; Jourdan, N.; Roussel, P. Sirtuin 7 promotes 45 S pre-rRNA cleavage at site 2 and determines the processing pathway. J. Cell Sci. 2019, 132, jcs228601. [CrossRef] 
132. Iyer-Bierhoff, A.; Krogh, N.; Tessarz, P.; Ruppert, T.; Nielsen, H.; Grummt, I. SIRT7-dependent deacetylation of fibrillarin controls histone H2A methylation and rRNA synthesis during the cell cycle. Cell Rep. 2018, 25, 2946-2954. [CrossRef] [PubMed]

133. Iyer-Bierhoff, A.; Grummt, I. Stop-and-Go: Dynamics of Nucleolar Transcription During the Cell Cycle. Epigene. Insights 2019, 12, 2516865719849090. [CrossRef]

134. Frescas, D.; Guardavaccaro, D.; Bassermann, F.; Koyama-Nasu, R.; Pagano, M. JHDM1B/FBXL10 is a nucleolar protein that represses transcription of ribosomal RNA genes. Nature 2007, 450, 309-313. [CrossRef] [PubMed]

135. Tanaka, Y.; Yano, H.; Ogasawara, S.; Yoshioka, S.; Imamura, H.; Okamoto, K.; Tsuneoka, M. Mild glucose starvation induces KDM2A-mediated H3K36me2 demethylation through AMPK to reduce rRNA transcription and cell proliferation. Mol. Cell. Biol. 2015, 35, 4170-4184. [CrossRef] [PubMed]

136. Galbiati, A.; Penzo, M.; Bacalini, M.G.; Onofrillo, C.; Guerrieri, A.N.; Garagnani, P.; Franceschi, C.; Treré, D.; Montanaro, L. Epigenetic up-regulation of ribosome biogenesis and more aggressive phenotype triggered by the lack of the histone demethylase JHDM1B in mammary epithelial cells. Oncotarget 2017, 8, 37091-37103. [CrossRef]

137. De Nicola, I.; Guerrieri, A.N.; Penzo, M.; Ceccarelli, C.; De Leo, A.; Trerè, D.; Montanaro, L. Combined expression levels of KDM2A and KDM2B correlate with nucleolar size and prognosis in primary breast carcinomas. Histol. Histopathol. 2020, 35, 1181-1187. [CrossRef]

138. Okamoto, K.; Tanaka, Y.; Ogasawara, S.; Obuse, C.; Nakayama, J.I.; Yano, H.; Tsuneoka, M. KDM2A-dependent reduction of rRNA transcription on glucose starvation requires HP1 in cells, including triple-negative breast cancer cells. Oncotarget 2019, 10, 4743-4760. [CrossRef]

139. Feng, W.; Yonezawa, M.; Ye, J.; Jenuwein, T.; Grummt, I. PHF8 activates transcription of rRNA genes through H3K4me3 binding and H3K9me1/2 demethylation. Nat. Struct Mol. Biol. 2010, 17, 445-450. [CrossRef]

140. Ulicna, L.; Kalendova, A.; Kalasova, I.; Vacik, T.; Hozák, P. PIP2 epigenetically represses rRNA genes transcription interacting with PHF8. Biochim. Biophys Acta Mol. Cell Biol. Lipids 2018, 1863, 266-275. [CrossRef]

141. Ke, R.; Xu, Q.; Li, C.; Luo, L.; Huang, D. Mechanisms of AMPK in the maintenance of ATP balance during energy metabolism. Cell Biol. Int. 2018, 42, 384-392. [CrossRef]

142. Hannan, K.M.; Brandenburger, Y.; Jenkins, A.; Sharkey, K.; Cavanaugh, A.; Rothblum, L.; Moss, T.; Poortinga, G.; McArthur, G.A. mTOR-dependent regulation of ribosomal gene transcription requires S6K1 and is mediated by phosphorylation of the carboxy-terminal activation domain of the nucleolar transcription factor UBF. Mol. Cell. Biol. 2003, 23, 8862-8877. [CrossRef]

143. Mayer, C.; Zhao, J.; Yuan, X.; Grummt, I. mTOR-dependent activation of the transcription factor TIF-IA links rRNA synthesis to nutrient availability. Genes Dev. 2004, 18, 423-434. [CrossRef] [PubMed]

144. Hannan, K.M.; Sanij, E.; Hein, N.; Hannan, R.D.; Pearson, R.B. Signaling to the ribosome in cancer-It is more than just mTORC1. IUBMB Life 2011, 63, 79-85. [CrossRef] [PubMed]

145. Von Walden, F. Ribosome biogenesis in skeletal muscle: Coordination of transcription and translation. J. Appl. Physiol. 2019, 127, 591-598. [CrossRef]

146. Hoppe, S.; Bierhoff, H.; Cado, I.; Weber, A.; Tiebe, M.; Grummt, I.; Voit, R. AMP-activated protein kinase adapts rRNA synthesis to cellular energy supply. Proc. Natl. Acad. Sci. USA 2009, 106, 17781-17786. [CrossRef] [PubMed]

147. Murayama, A.; Ohmori, K.; Fujimura, A.; Minami, H.; Yasuzawa-Tanaka, K.; Kuroda, T.; Oie, S.; Daitoku, H.; Okuwaki, M.; Nagata, K.; et al. Epigenetic control of rDNA loci in response to intracellular energy status. Cell 2008, 133, 627-639. [CrossRef] [PubMed]

148. Kumazawa, T.; Nishimura, K.; Kuroda, T.; Ono, W.; Yamaguchi, C.; Katagiri, N.; Tsuchiya, M.; Masumoto, H.; Nakajima, Y.; Murayama, A.; et al. Novel nucleolar pathway connecting intracellular energy status with p53 activation. J. Biol. Chem. 2011, 286, 20861-20869. [CrossRef] [PubMed]

149. Yang, L.; Song, T.; Chen, L.; Kabra, N.; Zheng, H.; Koomen, J.; Seto, E.; Chen, J. Regulation of SirT1-nucleomethylin binding by rRNA coordinates ribosome biogenesis with nutrient availability. Mol. Cell. Biol. 2013, 33, 3835-3848. [CrossRef]

150. Yang, L.; Song, T.; Chen, L.; Soliman, H.; Chen, J. Nucleolar repression facilitates initiation and maintenance of senescence. Cell Cycle 2015, 14, 3613-3623. [CrossRef] [PubMed]

151. Waku, T.; Nakajima, Y.; Yokoyama, W.; Nomura, N.; Kako, K.; Kobayashi, A.; Shimizu, T.; Fukamizu, A. NML-mediated rRNA base methylation links ribosomal subunit formation to cell proliferation in a p53-dependent manner. J. Cell Sci. 2016, 129, 2382-2393. [CrossRef]

152. Zhao, Z.; Dammert, M.A.; Grummt, I.; Bierhoff, H. lncRNA-Induced Nucleosome Repositioning Reinforces Transcriptional Repression of rRNA Genes upon Hypotonic Stress. Cell Rep. 2016, 14, 1876-1882. [CrossRef] [PubMed]

153. Zhao, Z.; Dammert, M.A.; Hoppe, S.; Bierhoff, H.; Grummt, I. Heat shock represses rRNA synthesis by inactivation of TIF-IA and lncRNA-dependent changes in nucleosome positioning. Nucleic Acids Res. 2016, 44, 8144-8152. [CrossRef] [PubMed]

154. Zhao, Z.; Sentürk, N.; Song, C.; Grummt, I. lncRNA PAPAS tethered to the rDNA enhancer recruits hypophosphorylated CHD4/NuRD to repress rRNA synthesis at elevated temperatures. Genes Dev. 2018, 32, 836-848. [CrossRef]

155. Mayer, C.; Bierhoff, H.; Grummt, I. The nucleolus as a stress sensor: JNK2 inactivates the transcription factor TIF-IA and down-regulates rRNA synthesis. Genes Dev. 2005, 19, 933-941. [CrossRef] [PubMed]

156. Audas, T.E.; Jacob, M.D.; Lee, S. Immobilization of proteins in the nucleolus by ribosomal intergenic spacer noncoding RNA. Mol. Cell 2012, 45, 147-157. [CrossRef] 
157. Audas, T.E.; Jacob, M.D.; Lee, S. The nucleolar detention pathway: A cellular strategy for regulating molecular networks. Cell Cycle 2012, 11, 2059-2062. [CrossRef]

158. Yap, K.; Mukhina, S.; Zhang, G.; Tan, J.S.C.; Ong, H.S.; Makeyev, E.V. A Short Tandem Repeat-Enriched RNA Assembles a Nuclear Compartment to Control Alternative Splicing and Promote Cell Survival. Mol. Cell 2018, 72, 525-540. [CrossRef]

159. Jacob, M.D.; Audas, T.E.; Uniacke, J.; Trinkle-Mulcahy, L.; Lee, S. Environmental cues induce a long noncoding RNA-dependent remodeling of the nucleolus. Mol. Biol. Cell 2013, 24, 2943-2953. [CrossRef]

160. Wang, M.; Tao, X.; Jacob, M.D.; Bennett, C.A.; Ho, J.J.D.; Gonzalgo, M.L.; Audas, T.E.; Lee, S. Stress-Induced Low Complexity RNA Activates Physiological Amyloidogenesis. Cell Rep. 2018, 24, 1713-1721. [CrossRef]

161. Theodoridis, P.R.; Bokros, M.; Marijan, D.; Balukoff, N.C.; Wang, D.; Kirk, C.C.; Budine, T.D.; Goldsmith, H.D.; Wang, M.; Audas, T.E.; et al. Local translation in nuclear condensate amyloid bodies. Proc. Natl. Acad. Sci. USA 2021, 118, e2014457118. [CrossRef]

162. Abraham, K.J.; Khosraviani, N.; Chan, J.N.Y.; Gorthi, A.; Samman, A.; Zhao, D.Y.; Wang, M.; Bokros, M.; Vidya, E.; Ostrowski, L.A.; et al. Nucleolar RNA polymerase II drives ribosome biogenesis. Nature 2020, 585, 298-302. [CrossRef] [PubMed]

163. Nadel, J.; Athanasiadou, R.; Lemetre, C.; Wijetunga, N.A.; Ó Broin, P.; Sato, H.; Zhang, Z.; Jeddeloh, J.; Montagna, C.; Golden, A.; et al. RNA:DNA hybrids in the human genome have distinctive nucleotide characteristics, chromatin composition, and transcriptional relationships. Epigenet. Chromatin. 2015, 8, 46. [CrossRef]

164. Yan, Q.; Zhu, C.; Guang, S.; Feng, X. The Functions of Non-coding RNAs in rRNA Regulation. Front. Genet. 2019, 10, 290. [CrossRef] [PubMed]

165. McCann, K.L.; Baserga, S.J. Driving nucleolar assembly. Genes Dev. 2014, 28, 211-213. [CrossRef] [PubMed]

166. Van Sluis, M.; McStay, B. Nucleolar reorganization in response to rDNA damage. Curr. Opin. Cell Biol. 2017, 46, 81-86. [CrossRef] [PubMed]

167. Van Sluis, M.; McStay, B. Nucleolar DNA Double-Strand Break Responses Underpinning rDNA Genomic Stability. Trends Genet. 2019, 35, 743-753. [CrossRef]

168. Caudron-Herger, M.; Pankert, T.; Rippe, K. Regulation of nucleolus assembly by non-coding RNA polymerase II transcripts. Nucleus 2016, 7, 308-318. [CrossRef]

169. Mars, J.C.; Tremblay, M.G.; Valere, M.; Sibai, D.S.; Sabourin-Felix, M.; Lessard, F.; Moss, T. The chemotherapeutic agent CX-5461 irreversibly blocks RNA polymerase I initiation and promoter release to cause nucleolar disruption, DNA damage and cell inviability. NAR Cancer 2020, 2, zcaa032. [CrossRef]

170. Hirai, H. Chromosome Dynamics Regulating Genomic Dispersion and Alteration of Nucleolus Organizer Regions (NORs). Cells 2020, 9, 971. [CrossRef] [PubMed]

171. Harding, S.M.; Boiarsky, J.A.; Greenberg, R.A. ATM Dependent Silencing Links Nucleolar Chromatin Reorganization to DNA Damage Recognition. Cell Rep. 2015, 13, 251-259. [CrossRef]

172. Van Sluis, M.; McStay, B. A localized nucleolar DNA damage response facilitates recruitment of the homology-directed repair machinery independent of cell cycle stage. Genes Dev. 2015, 29, 1151-1163. [CrossRef]

173. Floutsakou, I.; Agrawal, S.; Nguyen, T.T.; Seoighe, C.; Ganley, A.R.; McStay, B. The shared genomic architecture of human nucleolar organizer regions. Genome Res. 2013, 23, 2003-2012. [CrossRef] [PubMed]

174. Caudron-Herger, M.; Pankert, T.; Seiler, J.; Németh, A.; Voit, R.; Grummt, I.; Rippe, K. Alu element-containing RNAs maintain nucleolar structure and function. EMBO J. 2015, 34, 2758-2774. [CrossRef] [PubMed]

175. Xing, Y.-H.; Yao, R.-W.; Zhang, Y.; Guo, C.-J.; Jiang, S.; Xu, G.; Dong, R.; Yang, L.; Chen, L.-L. SLERT Regulates DDX21 Rings Associated with Pol I Transcription. Cell 2017, 169, 664-678. [CrossRef] [PubMed]

176. Li, D.; Zhang, J.; Wang, M.; Li, X.; Gong, H.; Tang, H.; Chen, L.; Wan, L.; Liu, Q. Activity dependent LoNA regulates translation by coordinating rRNA transcription and methylation. Nat. Commun. 2018, 9, 1726. [CrossRef]

177. Voit, R.; Hoffmann, M.; Grummt, I. Phosphorylation by G1-specific cdk-cyclin complexes activates the nucleolar transcription factor UBF. EMBO J. 1999, 18, 1891-1899. [CrossRef]

178. Voit, R.; Grummt, I. Phosphorylation of UBF at serine 388 is required for interaction with RNA polymerase I and activation of rDNA transcription. Proc. Natl. Acad. Sci. USA 2001, 98, 13631-13636. [CrossRef]

179. Stefanovsky, V.Y.; Pelletier, G.; Hannan, R.; GagnonKugler, T.; Rothblum, L.I.; Moss, T. An immediate response of ribosomal transcription to growth factor stimulation in mammals is mediated by ERK phosphorylation of UBF. Mol. Cell 2001, 8, 1063-1073. [CrossRef]

180. Zhao, J.; Yuan, X.; Fro, M.; Grummt, I. ERK-Dependent Phosphorylation of the Transcription Initiation Factor TIF-IA Is Required for RNA Polymerase, I. Transcr. Cell Growth. Mol. Cell 2003, 11, 405-413. [CrossRef]

181. Zhang, C.; Comai, L.; Johnson, D.L. PTEN represses RNA Polymerase I transcription by disrupting the SL1 complex. Mol. Cell. Biol. 2005, 25, 6899-6911. [CrossRef] [PubMed]

182. Liang, H.; Chen, X.; Yin, Q.; Ruan, D.; Zhao, X.; Zhang, C.; McNutt, M.A.; Yin, Y. PTEN $\beta$ is an alternatively translated isoform of PTEN that regulates rDNA transcription. Nat. Commun. 2017, 8, 14771. [CrossRef] [PubMed]

183. Lessard, F.; Morin, F.; Ivanchuk, S.; Langlois, F.; Stefanovsky, V.; Rutka, J.; Moss, T. The ARF tumor suppressor controls ribosome biogenesis by regulating the RNA polymerase I transcription factor TTF-I. Mol. Cell 2010, 38, 539-550. [CrossRef] [PubMed]

184. Liu, L.; Pilch, P.F. PTRF/Cavin-1 promotes efficient ribosomal RNA transcription in response to metabolic challenges. eLife 2016, 5, e17508. [CrossRef] [PubMed]

185. Liu, L. Lessons from cavin-1 deficiency. Biochem. Soc. Trans. 2020, 48, 147-154. [CrossRef] 
186. Shiue, C.-N.; Berkson, R.G.; Wright, A.P.H. c-Myc induces changes in higher order rDNA structure on stimulation of quiescent cells. Oncogene 2009, 28, 1833-1842. [CrossRef]

187. Zhou, Y.; Schmitz, K.M.; Mayer, C.; Yuan, X.; Akhtar, A.; Grummt, I. Reversible acetylation of the chromatin remodelling complex NoRC is required for non-coding RNA-dependent silencing. Nat. Cell Biol. 2009, 11, 1010-1016. [CrossRef]

188. Santoro, R.; Schmitz, K.M.; Sandoval, J.; Grummt, I. Intergenic transcripts originating from a subclass of ribosomal DNA repeats silence ribosomal RNA genes in trans. EMBO Rep. 2010, 11, 52-58. [CrossRef]

189. Guetg, C.; Lienemann, P.; Sirri, V.; Grummt, I.; Hernandez-Verdun, D.; Hottiger, M.O.; Fussenegger, M.; Santoro, R. The NoRC complex mediates the heterochromatin formation and stability of silent rRNA genes and centromeric repeats. EMBO J. 2010, 29, 2135-2146. [CrossRef]

190. Lee, D.; An, J.; Park, Y.U. SHPRH regulates rRNA transcription by recognizing the histone code in an mTOR-dependent manner. Proc. Natl. Acad. Sci. USA 2017, 114, E3424-E3433. [CrossRef]

191. Lee, D.; Park, J.H.; Kim, S.; Lee, S.G.; Myung, K. SHPRH as a new player in ribosomal RNA transcription and its potential role in homeostasis of ribosomal DNA repeats. Transcription 2018, 9, 190-195. [CrossRef] [PubMed]

192. Sarshad, A.; Sadeghifar, F.; Louvet, E.; Mori, R.; Böhm, S.; Al-Muzzaini, B.; Vintermist, A.; Fomproix, N.; Östlund, A.K.; Percipalle, P. Nuclear myosin 1c facilitates the chromatin modifications required to activate rRNA gene transcription and cell cycle progression. PLoS Genet. 2013, 9, e1003397. [CrossRef] [PubMed]

193. Tsai, Y.C.; Greco, T.M.; Boonmee, A.; Miteva, Y.; Cristea, I.M. Functional proteomics establishes the interaction of SIRT7 with chromatin remodeling complexes and expands its role in regulation of RNA polymerase I transcription. Mol. Cell. Proteom. 2012, 11, 60-76. [CrossRef]

194. Kiran, S.; Anwar, T.; Kiran, M.; Ramakrishna, G. Sirtuin 7 in cell proliferation, stress and disease: Rise of the Seventh Sirtuin! Cell Signal. 2015, 27, 673-682. [CrossRef] [PubMed]

195. Barnett, C.; Yazgan, O.; Kuo, H.C.; Malakar, S.; Thomas, T.; Fitzgerald, A.; Harbour, W.; Henry, J.J.; Krebs, J.E. Williams Syndrome Transcription Factor is critical for neural crest cell function in Xenopus laevis. Mech. Dev. 2012, 129, 324-338. [CrossRef]

196. Franek, M.; Kovaříková, A.; Bártová, E.; Kozubek, S. Nucleolar Reorganization Upon Site-Specific Double-Strand Break Induction. J. Histochem. Cytochem. 2016, 64, 669-686. [CrossRef] 